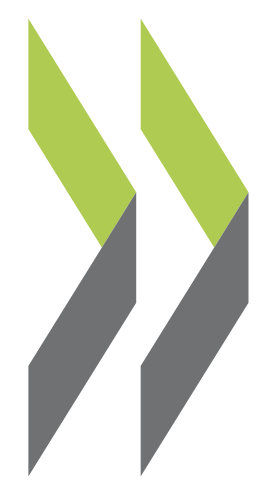

OECD Economics Department Working Papers No. 647

Speed of Adjustment to Selected Labour Market and Tax Reforms

Annabelle Mourougane, Lukas Vogel 
Organisation de Coopération et de Développement Économiques

Organisation for Economic Co-operation and Development

28-Oct-2008

ECONOMICS DEPARTMENT

English - Or. English

SPEED OF ADJUSTMENT TO SELECTED LABOUR MARKET AND TAX REFORMS

ECONOMICS DEPARTMENT WORKING PAPER No. 647

By Annabelle Mourougane and Lukas Vogel

All OECD Economics Department Working Papers are available on the OECD internet website at www.oecd.org/eco/working_papers

JT03254002

Document complet disponible sur OLIS dans son format d'origine

Complete document available on OLIS in its original format 


\section{ABSTRACT / RÉSUMÉ \\ Speed of adjustment to selected labour market and tax reforms}

This paper examines the nature and the length of economic adjustments to selected structural reforms, drawing on a variety of approaches: descriptive analysis and simulations using Dynamic General Equilibrium and macro-economic neo-Keynesian models. The descriptive analysis suggests that the correlation between reforms, including a change in the tax wedge, the replacement ratio or anti-competitive product market regulation and the structural unemployment rate peaks only after 5 to 10 years. Lowering employment and price adjustment costs in the euro area to their respective US levels would only have a relatively limited effect on the speed of adjustment to labour market and tax reforms. Monetary policy reaction can speed up the adjustment to a new equilibrium, though to a varying degree in the different OECD countries or regions. In particular, reforms in individual euro area countries are likely to trigger only little or no policy reaction, unless there is an area-wide effort to implement reforms.

JEL classification codes: C5; E5; E00; G10

Keywords: structural reforms; adjustment speed; Dynamic General Equilibrium model; neo-Keynesian models; adjustment costs; euro area; United States; monetary policy; Taylor rule

$* * * * * * * * * *$

\section{Vitesse d'ajustement à des réformes sur le marché du travail et de la fiscalité}

Cet article examine la nature et la durée des ajustements économiques à un certain nombre de réformes structurelles, utilisant plusieurs approches: analyse descriptive et simulations des modèles dynamique d'équilibre général et macro-économiques néo-keynésiens, L'analyse descriptive suggère que la corrélation entre des réformes, notamment une modification du coin fiscal, du taux de remplacement et des régulations anticoncurrentielles sur le marché des produits et le taux de chômage structurel n'atteint son effet maximum qu'après 5 à 10 ans. Diminuer les coûts d'ajustement sur l'emploi et les prix de la zone euro à leur niveau observé aux États-Unis ne se traduirait que par des effets limités sur la vitesse d'ajustements aux réformes sur le marché du travail ou aux réformes fiscales. Une réaction de politique monétaire peut accélérer l'ajustement à un nouvel équilibre, mais de manière plus ou moins marquée dans les différents pays ou régions de l'OCDE. En particulier, les réformes menées au niveau des pays individuels généreront probablement peu ou pas de réaction monétaire, sauf en présence d'un effort concerté de mise en œuvre de réformes au niveau de la zone.

Classification JEL : C5 ; E5 ; E00 ; G10

Mots clefs : réformes structurelles; vitesse d'ajustement; modèle dynamique d'équilibre général; modèle néo-keynésiens; coûts d'ajustement; zone euro; États-Unis; politique monétaire; règle de Taylor

\section{Copyright OECD, 2008}

Application for permission to reproduce or translate all, or part of, this material should be made to: Head of Publications Service, OECD, 2 rue André Pascal, 75775 Paris Cedex 16, France. 


\section{TABLE OF CONTENTS}

Speed of adjustment to selected labour market and tax reforms.............................................................. 5

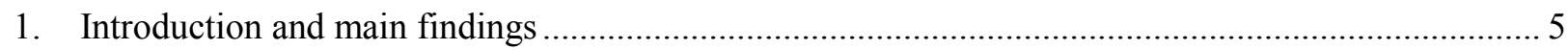

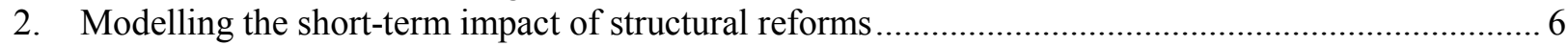

3. Impact of institutional changes on structural unemployment ................................................... 9

4. Labour and product market rigidities and adjustment speed................................................... 13

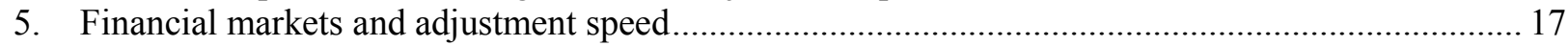

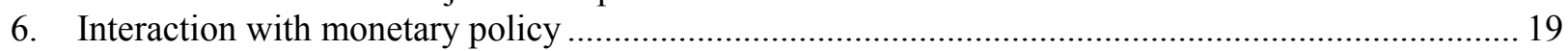

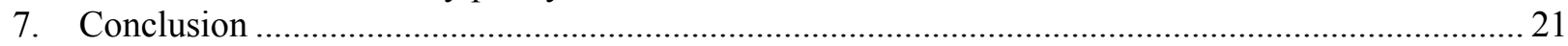

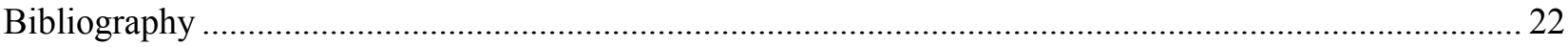

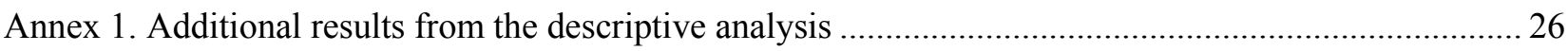

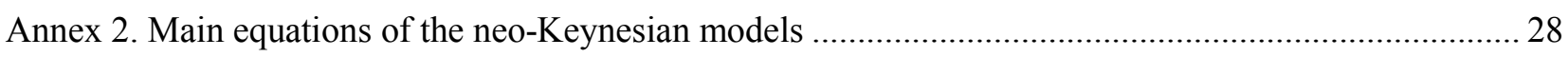

Annex 3: The micro-founded Dynamic General Equilibrium model …....................................................... 33

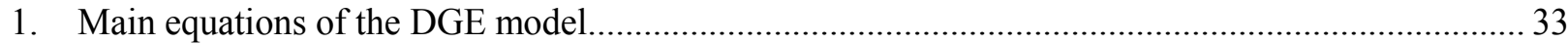

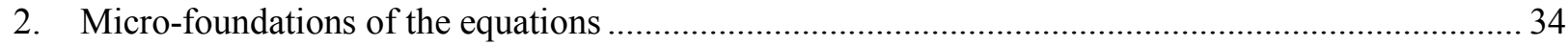

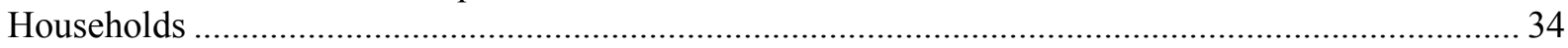

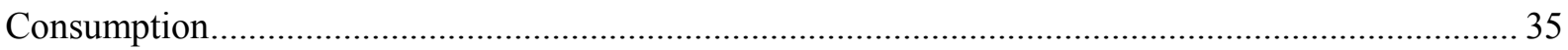

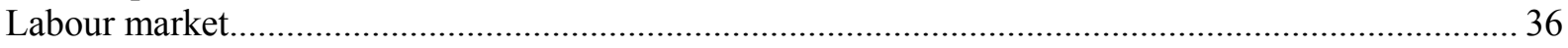

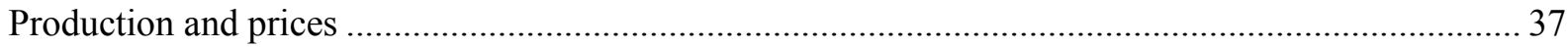

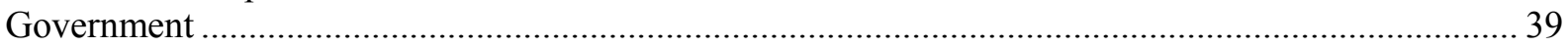

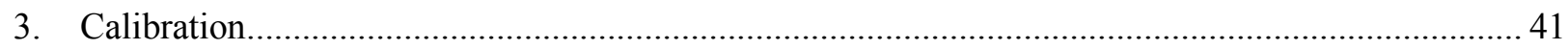

Annex 4: Additional impulse responses from the DGE model................................................................. 43

Annex 5: Detailed results of the neo-Keynesian simulations ......................................................................... 47

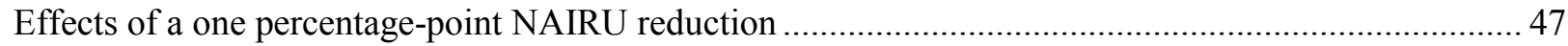

\section{Boxes}

Box 1. Main features of the neo-Keynesian small models .................................................................... 7

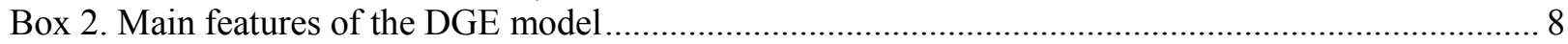




\section{$\mathrm{ECO} / \mathrm{WKP}(2008) 55$}

\section{Tables}

A.3.1. Calibration of the parameters

\section{Figures}

1. Structural unemployment and contributions of institutions in the OECD

2. Correlation between the change in institutions and cumulative changes in the NAIRU

3. Impact of a one-percentage point cut in the income tax rate

4. Impact of a one percentage-point income tax cut with nominal wage stickiness

5. Impact of a one percentage-point income tax cut in a search-and-matching framework

6. Impact of a one percentage-point income tax cut under alternative share of liquidity-constrained households in the euro area

7. Effect of monetary policy on adjustment to a one percentage-point NAIRU decline

8. Impact of a one percentage point decline in the NAIRU under alternative monetary policy reactions

A.1. Structural unemployment and contributions of institutions in the European Union

A.2. Structural unemployment and contributions of institutions in the United States

A.4.1. Impact of a one percentage-point cut in the benefit replacement rate

A.4.2. Impact of a one percentage-point cut in social security contributions

A.4.3. One percentage-point cut in the benefit replacement rate in the search-and-matching model

A.4.4. One percentage point cut in the social security contributions in the search-and-matching model 
ECO/WKP(2008)55

\title{
SPEED OF ADJUSTMENT TO SELECTED LABOUR MARKET AND TAX REFORMS
}

\author{
by Annabelle Mourougane and Lukas Vogel ${ }^{1}$
}

\section{Introduction and main findings}

1. The long-term impact of structural reforms on economic performance has been studied in depth, in particular in the context of the revisited 2006 OECD Jobs Strategy. The impact of institutions on adjustment to temporary shocks is also well-documented (Duval et al., 2007; Ernst et al., 2007; Inklaar and Timmer, 2006). By contrast, few analyses have focused on transitional effects of structural reforms and adjustments from one steady state to another. It is indeed not easy to empirically disentangle the effects coming from a shift in the steady state from the transitional adjustment dynamics. The lack of analysis also reflects the limited temporal dimension of institutional variables.

2. Nonetheless, analysing the adjustment path is important for political economy reasons. It gives an idea of the time needed to see the impact of reforms on economic performance, thereby putting long-term benefits in perspective. Having a clearer idea of the adjustment lags associated with structural policies is also useful for macroeconomic stabilisation decisions and helps policymakers gauge the complementarities between structural adjustment and monetary or fiscal accommodation.

3. Against this background, this paper examines the nature and the length of economic adjustment to selected structural reforms, drawing on a variety of approaches. First, the impact of institutional reforms on equilibrium unemployment is analysed through simple descriptive analyses. Second, simulations using two different types of models, namely small macro-economic neo-Keynesian models and a micro-founded dynamic general equilibrium (DGE) model, give insight on how existing rigidities in labour and product markets and characteristics of financial markets affect the pace of adjustment to structural reforms. They also help to quantify the impact of monetary policy reaction on the speed of adjustment.

4. The main conclusions are the following:

- The descriptive analysis suggests that the correlation between structural reforms, including a change in the tax wedge, the replacement ratio or anti-competitive product market regulation ${ }^{2}$ and structural unemployment is maximal only after 5 to 10 years.

- Lowering employment and price adjustment costs in the euro area to their respective US levels would only have a relatively limited effect on the speed of adjustment to labour market and tax reforms. This result is robust to the choice of the policy variables (income tax, benefit replacement rate or employer social security contributions) and holds for both neo-Keynesian and DGE-based simulations. This contrasts with the significant heterogeneity across the two

1. The authors are working at the OECD Economics Department. They would like to especially thank Jørgen Elmeskov, who suggested the topic. They are grateful to Jonathan Coppel, Davide Furceri, Claude Giorno, Peter Hoeller, Vincent Koen and Jean-Luc Schneider for helpful discussions and suggestions and Penny Elghadab for valuable editorial support. They also thank the participants of the $14^{\text {th }}$ Dubrovnik Conference, in particular Maroje Lang. The views expressed in this paper do not necessarily reflect those of the OECD.

2. Evidence of complementarities between product and labour market reforms can be found in Nicoletti and Scarpetta (2005). 
sides of the Atlantic in economic resilience to temporary cyclical shocks (Duval et al., 2007), but the different nature of the shocks and their duration in the two approaches explain this divergence.

- Full access to well-performing financial markets will also affect adjustment speed by easing firms and household liquidity constraints. DGE-based simulations suggest however that the presence of liquidity-constrained households would be partly offset by a stronger monetary policy reaction and hence, the final effect on the adjustment of real variables would be limited. By omitting capital adjustments, these simulations may nonetheless underestimate the effects of easing household liquidity constraints on adjustment to structural reforms.

- Macro-economic policy can have a sizable impact on the magnitude of short-term transition costs. In particular, monetary policy reaction can speed up the adjustment to a new equilibrium though to a varying degree in the different OECD countries or regions. Reforms in individual euro area countries are likely to trigger only little or no policy reaction, unless there is an area-wide effort to implement structural reforms. The speed of adjustment is found to be faster in the United States than in the euro area, reflecting mostly a higher sensitivity of domestic demand to real interest rates. This result appears to be robust to the choice of the euro area monetary policy reaction.

5. The paper first discusses the different methodologies used to quantify short-term impact of structural reforms and, based on a set of institutional variables available for 20 OECD countries over 20 years, it reports findings on the delay of adjustment to reforms. The paper then examines the effects of product and labour market rigidities and of financial market developments on the adjustment speed. Finally, it analyses the interaction between structural reforms and the conduct of monetary policy. A final section concludes.

\section{Modelling the short-term impact of structural reforms}

6. There is little analysis on the short-term impact of structural reforms on economic performance, the main reason being the limited temporal variation of institutional variables. Studies based on singleequation cross-country panel estimations or industry-level difference-in-differences approaches have been widely used in the literature (Belot and van Ours, 2001; Bassanini and Duval, 2006; OECD, 2007). In these approaches, transmission channels from structural policies to macroeconomic performance are considered in isolation and a relationship links a performance indicator (e.g. the unemployment rate or productivity) to institutional variables. These analyses can be useful to assess the long-term impact of structural reforms but provide little information on the dynamics of adjustment as they are most of the time based on static equations. Empirical studies using institutional variables in panel estimation usually display limited time variation, so that only a small set of variables can be tested at a time. Moreover, these approaches fail to properly capture the fact that institutions that work in one way in one country may work differently elsewhere because the rest of the institutional structure differs (Duval and Vogel, 2008; Freeman, 1998). Interactions between institutions are usually proxied by product terms of the respective regressors but the ability of this approach to analyse a sequence of reforms tends to be rather limited (Dreger et al., 2007).

7. Most of the papers that have attempted to examine the short-term effects of structural reforms on economic performance rely on dynamic models, either neo-Keynesian or micro-founded DGE models (e.g. Bean, 1998; Coenen et al., 2007; Everaert and Schule, 2006). ${ }^{3}$ Neo-Keynesian models incorporate most of

3. There is, on the other hand, a richer literature on the effects of institutions on macroeconomic resilience and the absorption of exogenous shocks. Examples include Campolmi and Faia (2007), Duval et al. (2007), Ernst et al. (2007), Grenouilleau et al. (2007) and Smets and Wouters (2005). 
the traditional properties of large macroeconomic models (Box 1). They are well-suited to analyse the short-term impact of structural reforms as the lag structure of the model is determined by the empirical fit, i.e. country specificities. A major drawback is, however, the impossibility to introduce many relevant institutional variables directly in the model, the main exceptions being tax- and expenditure-related data. Simulations are thus generally limited to illustrative shocks on NAIRUs or mark-ups, the objective being to describe the adjustment mechanisms at play (Bean, 1998; Duval and Elmeskov, 2005; Hunt and Laxton, 2004). The ex post impact of reforms can also be examined using a two-step procedure whereby the shock on the NAIRU or mark-up is first calibrated off model using external information, for instance the impact of institutions on a reduced-form unemployment equation, and then simulated with a macroeconomic model. However, this strategy leads to unbiased estimates only if direct effects of institutions on economic performance are negligible.

\section{Box 1. Main features of the neo-Keynesian small models}

This box provides an overview of small models used to simulate a NAIRU shock in the United States, the euro area and France. A detailed description of the main equations is provided in Annex 2. Most behavioural equations are estimated in an error-correction form. The models are backward-looking: agents' expectations are treated implicitly by the inclusion of lags in the dependent variables. Real short-term rates are determined endogenously through a Taylor rule, with equal weights on inflation and the output gap.

The short-term behaviour of the model is influenced by standard Keynesian features through imperfectly flexible wages and prices, liquidity-constrained consumption, capital adjustment cost and labour hoarding. In the short term output is determined by demand. Unemployment and the output gap are important determinants of wage and price adjustments.

In the medium to long run, the supply side of the economy, which is modelled through a neo-classical production function, plays a prominent role. Factor demands are derived from profit maximisation. Prices and wages adjust and modify price competitiveness as well as relative factor prices and incomes. Output and unemployment move back to their long-term equilibrium levels.

More precisely, a decline in the NAIRU will have the following effects:

- $\quad$ Potential output immediately increases, leading to a negative output gap and a positive unemployment gap.

- $\quad$ Gaps exert downward pressure on prices and wages.

- Labour demand rises following the decline in real wages, and - as labour supply increases very slowly - the unemployment rate declines. Consumption and investment also react to these price and wage effects.

- Gaps and their resulting disinflationary effects trigger cuts in the policy interest rate. The reduction of real interest rates stimulates demand.

In an open economy, price and demand dynamics also affect trade flows. Consequently, the implementation of a structural reform in one specific country generates externalities for its major trading partners.

In the long run, the unemployment rate and output reach their equilibrium level, closing output and employment gaps. Inflation is coming back to baseline.

8. Alternatively the impact of structural reforms can be evaluated using DGE models that are explicitly derived from the optimisation of agents' behaviour under constraints (Box 2). This approach allows a wide range of structural reforms to be examined and possible spillovers between the variables to 
be taken into account. ${ }^{4}$ The use of DGE models presents a number of advantages. First, these models are less subject to the Lucas critique as they are based on structural equations with sound microeconomic foundations. Second, it is possible to assess different policies through their effects on consumer welfare. Finally, DGE models encompass dynamic effects and are well-honed to examine the adjustment to changes in economic structure and policy. However, the lag structure reflects the optimisation-based microfoundations and is generally limited and similar across regions or countries. Consequently, DGE results may tend to overemphasise similarities and to attribute differences to shocks rather than to economic structures. The empirical validation of DGE models is an important concern, but also an active field of economic research. Both the model dynamics and steady-state values can be quite sensitive to particular functional forms and parameter choices.

\section{Box 2. Main features of the DGE model}

This box describes the main features of the DGE model used to perform a number of policy simulations in the euro area, including a cut in the (unemployment) benefit replacement rate, an income tax rate cut and a cut in employer social security contributions. Details on the specification of the equations, the underlying theoretical framework and the calibration of the model are provided in Annex 3.

The DGE model assumes a closed economy with monopolistic competition in product and labour markets, which provides firms and unions with price and wage setting power. Firms use a bundle of differentiated labour services to produce a bundle of differentiated goods. Labour is the only production factor and yields constant returns to scale.

Firms incur both quadratic employment and price adjustment costs, which generate stickiness in employment and production and nominal price inertia. Assuming quadratic adjustment costs is indeed crucial to generate a spread-out employment and price response to exogenous shocks. Quadratic costs imply step-wise adjustment to be less costly than abrupt changes in employment levels or prices.

In addition to its traditional determinants, household consumption is affected by habit persistence. The higher the degree of habit persistence, the slower the adjustment of consumption and output to a structural reform. In the simulation this parameter has been set to 0.85 , consistent with Grenouilleau et al. (2007).

In an enriched version of the model, a heterogeneous household sector with two groups of consumers is considered. The first group maximises intertemporal utility over an infinite planning horizon in the presence of habit persistence (e.g. Fuhrer, 2000; Smets and Wouters, 2003). ${ }^{1}$ The second group is liquidity constrained households (the so-called rule-of-thumb households), has no access to financial markets for intertemporal income transfers and consequently spends their disposable period income entirely on current consumption (e.g. Galí et al., 2004, 2007).

In a different version of the model, the labour market displays wage rigidities or, alternatively, is modelled using a search and matching framework instead of a neoclassical labour market. This allows checking the robustness of results.

The main mechanisms at play following a cut in the policy variable (income tax, benefit replacement ratio or employer social security contributions) are:

- An income tax rate cut increases net real wage, labour supply and current disposable income, while a decrease in employer social security contributions directly reduces production costs and consequently dampens prices.

- Unemployment benefits can be assimilated to a reservation wage and reduce labour supply at given real wage levels. As a result, lower benefits will raise labour supply, even though they may temporarily reduce disposable income.

- $\quad$ Disposable income and consumption of liquidity-constrained households are affected by the way reforms are financed (self-financing of reforms or introduction of a scheme to balance the budget).

4. For instance, Coenen et al. (2007) examine the effects of temporary fiscal measures. Everaert and Schule (2006) use the IMF's global economy model to explore transitory costs of reforms. Imperfect competition in labour and product markets is modelled in a stylised manner through the existence of mark-ups. Similarly, Kilponen and Ripatti (2005) have investigated the quantitative effects of an increase in competition in both product and labour markets. Batini et al. (2005) examine the impact of combined fiscal adjustment and structural reforms for Japan. 
Forward-looking household and firm behaviour in the presence of price stickiness requires the introduction of a policy rule to ensure equilibrium stability and determinacy. For simplicity, interest rates are expected to react to current inflation: $i_{t}=-\ln \beta+\phi_{\pi} \pi_{t}$, with $\phi_{\pi}=1.5$ in all DGE-based simulations. The inclusion of an output gap in the policy rule would require choosing a specific definition of potential output within the DGE framework. As the ECB usually focuses on price stability, a monetary reaction function with inflation as the main determinant is a plausible assumption. The public budget is assumed to be balanced over the long-run.

1. An alternative assumption to introduce lags in the consumption equation would be to use a rule-of-thumb behaviour à la Amato and Laubach (2003), where a fraction of households replicates previous consumption levels, considering the latter as the best available forecast of future consumption.

9. In addition to the inherent limitations of these tools, the analysis of the short-term impact of structural reform is delicate as it sometimes mixes the adjustment of potential output to the new steady state with the adjustment of actual to potential production. In the two types of models used in this paper, the adjustment of potential output to the new steady state is instantaneous. It is possible, however, to model a gradual adjustment of potential output to the new steady state in neo-Keynesian models, where potential output is computed using a production function approach. One possibility would be to make potential output depend on actual (rather than desired) capital stocks or, alternatively, to endogenise the desired capital stock.

10. This paper does not seek to establish a ranking amongst the different methodologies, but takes an eclectic approach drawing on available methods and evidence. All the instruments described in this section display advantages and limitations to examine the short-term impact of structural reforms. They bring complementary information, emphasise several and different aspects of the topic and mutually provide some robustness checks of the results.

\section{Impact of institutional changes on structural unemployment}

11. The observation of past institutional data and how they have been related to economic performance in OECD countries over the last two decades provides some insights on the ex post effects of structural reforms. In particular, the empirical analysis undertaken in Bassanini and Duval (2006) helps to pinpoint the measures that had the most significant impact. In this work, the actual unemployment rate is expressed as a function of the output gap and of a number of institutional variables, including average replacement ratio, tax wedge between labour costs and take-home pay, employment protection legislation and product market regulation in non-manufacturing sectors. ${ }^{5}$ Time and country fixed effects are also included to account for omitted factors across countries and over time. A reduced form equation is then estimated in a sample of 20 OECD countries over the period 1983-2003. Tests indicate that the effects of these measures appear to be relatively robust across specifications.

12. A time-series indicator of the structural unemployment rate has been constructed for each country by subtracting the output gap estimates, as well as the error term from the actual unemployment rate, using coefficients from the Bassanini and Duval equation. The resulting structural unemployment rates are generally more volatile than the OECD Economic Outlook NAIRU estimates, which are derived from a Kalman-filter estimation and core price Phillips curves. However, both measures broadly display common patterns. The associated unemployment gaps evolve generally in line, although there are significant differences in some countries at some points in time (especially for Germany). Removing the country fixed

5. Other structural features such as union density or a measure of high corporatism are also included in the analysis, but their effects are found to be either very small or statistically insignificant. 
effects, as well as institutional variables that are not significant in the equation would shift the level of the structural unemployment rate up but would not significantly modify its pattern.

13. The estimated structural unemployment rate has declined markedly since 1995 in the OECD area as well as on average in the seven largest economies and the European Union (Figure 1 and Annex 1). This reflects a general trend towards product market liberalisation and a gradual decline in the tax wedge. Since the beginning of the decade, a reduction in the average replacement ratio has also contributed to the fall. Arpaia et al. (2007) suggest that these trends have continued in recent years.

14. Although there has been a clear trend toward product market liberalisation with no subsequent reversals, there is no uniform pattern with regards to labour market reforms across OECD countries. Moreover, within a single country some labour market reforms may not be sustained over time and policy reversals can sometimes be observed (OECD, 2008). This renders the identification of the short-term impact of structural reforms particularly delicate: for instance, it is difficult to disentangle a weak impact of initial reforms on economic performance from an adverse impact of subsequent backtracking.

Figure 1. Structural unemployment and contributions of institutions in the OECD
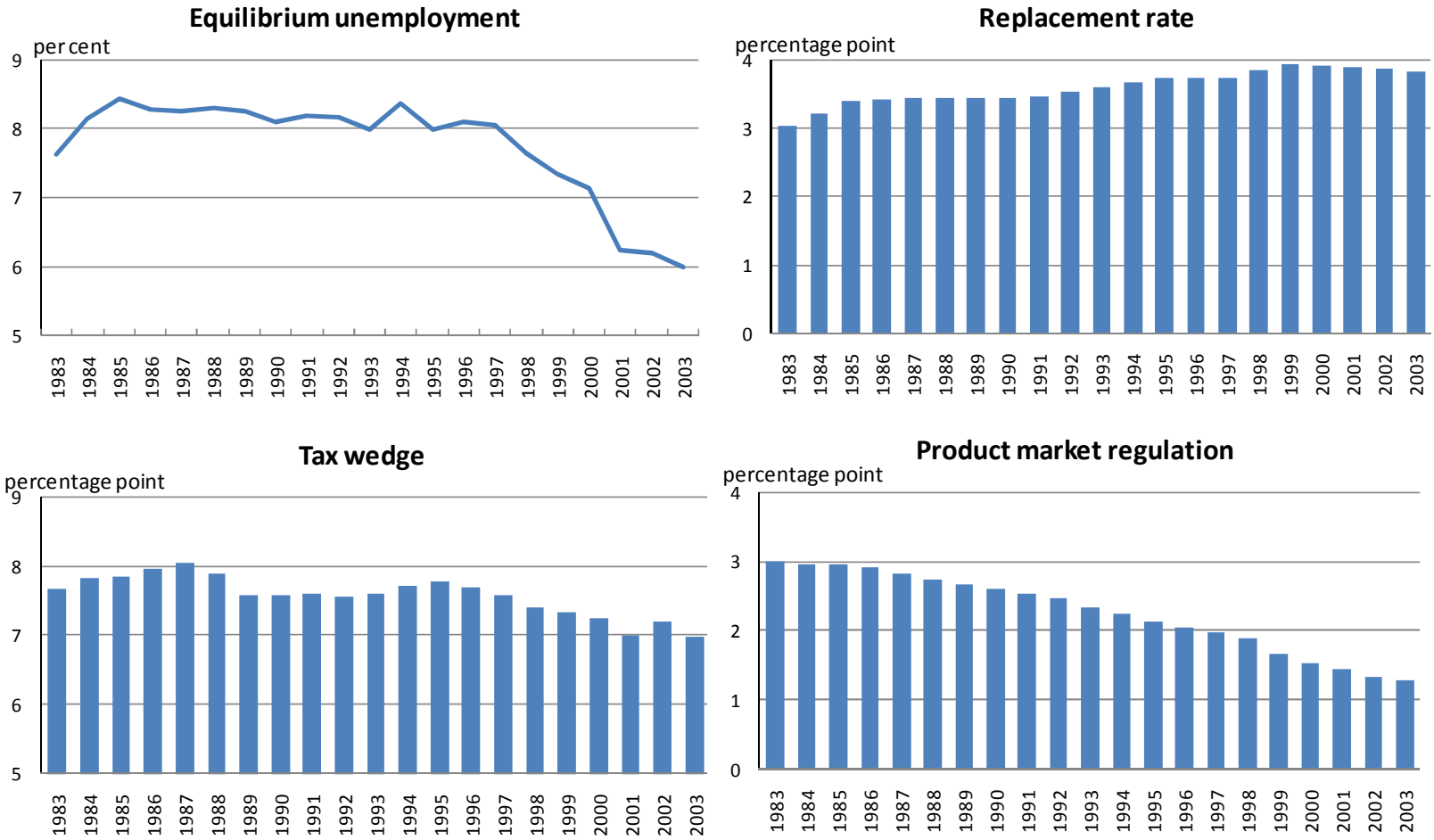

Note: The sample includes the 20 countries examined in Bassanini and Duval (2006). Germany, Finland and Sweden have been removed from the calculation because a break has been introduced for these countries in the estimations.

15. Aggregate developments can mask large differences across countries. However, three institutions appear to play a major role in explaining the evolution of structural unemployment in individual countries over the period 1983-2003:

- Amongst all the institutional variables, the tax wedge contributed the most to explain the level of structural unemployment in most OECD countries. ${ }^{6}$ There is no clear pattern as to how the tax wedge has evolved over time or across OECD countries. It has steadily declined

6. It should be noted however that this reflects the specific measure used. A national-accounts based measure would lead to a lower contribution. 
in the United States, Italy and the United Kingdom, but has risen in Japan, France and Canada. It has experienced ups and downs in Germany.

- A significant part of structural unemployment is also explained by the average replacement rate in selected countries. Here again, this variable displays no clear international trend.

- In addition to these labour market institutions, product market regulations are also estimated to have had a sizable impact on the structural unemployment rate. A consistent and marked decline in the indicator, signalling the move toward more competitive markets, is visible in most OECD economies. This is particularly true for Anglo-Saxon countries, where product markets reforms started earlier than in continental Europe.

- By contrast, changes in employment protection legislation have played a minor role, except in a few European countries like Germany, Italy and the United Kingdom.

16. In order to give some insights on the adjustment process and the lagged effects of structural reforms, correlations have been computed between the cumulative increase in the NAIRU between time t-i and $t$ and the change in the institution at time $t-i$ (Figure 2$).^{7}$ It appears that:

- A change in institutions, in particular the tax wedge, the replacement ratio and product market regulation, are associated with gradual changes in NAIRU. The correlation peaks after 5 to 10 years, depending on the measure considered.

- In the short-term the maximum correlation is obtained for the tax wedge and product market regulations and is significant. ${ }^{8}$ Correlations rise over the first four years and then gradually diminish, ending up close to zero after 7 years. By contrast, correlations between NAIRUs and product market regulations continue to display a significant though small effect over 10 years.

- The correlation between the change in the average replacement ratio and the change in the NAIRU is negligible in the short term, but gradually increases over time, implying very long lags in the adjustment process. The correlation becomes significant only after a decade or so.

- The correlation between a change in employment protection legislation (EPL) and a change in the NAIRU remains insignificant over a ten-year period. This result holds for both temporary and regular contracts.

17. These results are subject to a number of caveats. The correlations have been computed using a small number of observations and may be distorted by the presence of other, omitted determinants of structural unemployment. Moreover, Granger tests fail to provide robust evidence of causality between institutions and NAIRUs across countries. ${ }^{9}$

7. In this subsection, OECD Economic Outlook NAIRUs rather than structural unemployment rates have been used as the latter are by construction correlated with institutions. NAIRUs and structural unemployment rates usually display similar trends in OECD countries, but some levels differences can be observed for some countries.

8. A simple rule of thumb derived from regression analysis is that the correlation is significant when it exceeds 0.1 in absolute value.

9. Results are available on request. 
Figure 2. Correlation between the change in institutions and cumulative changes in the NAIRU
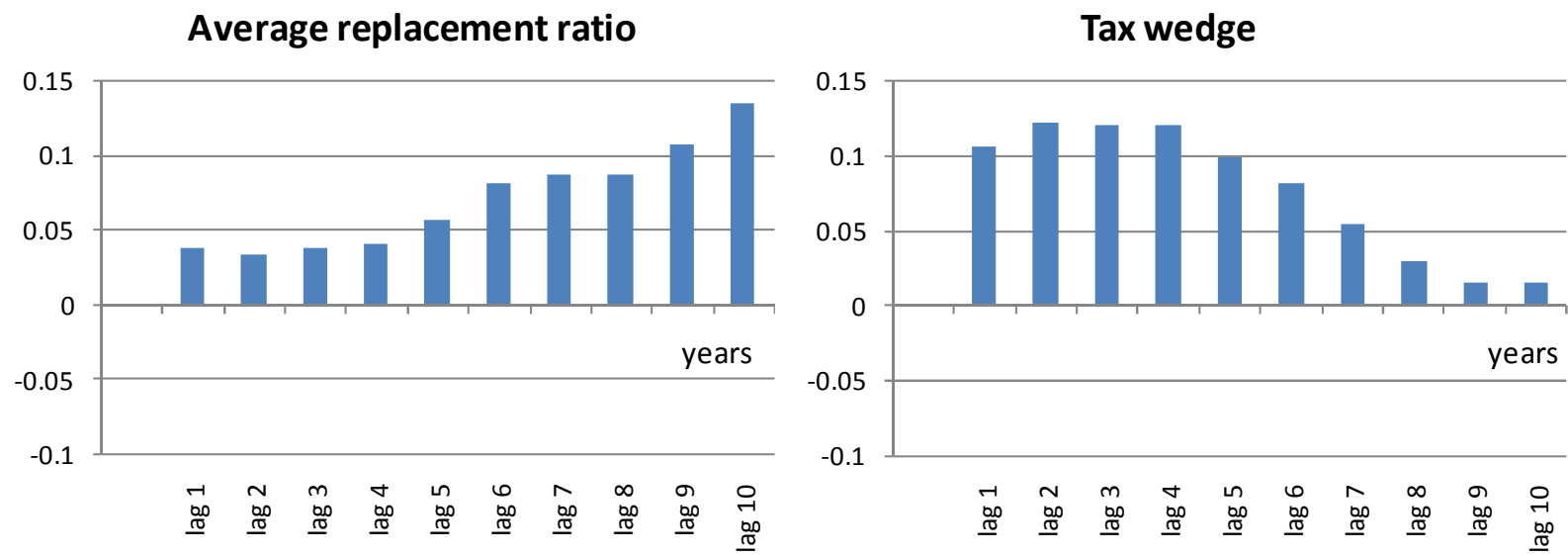

Employment protection legislation
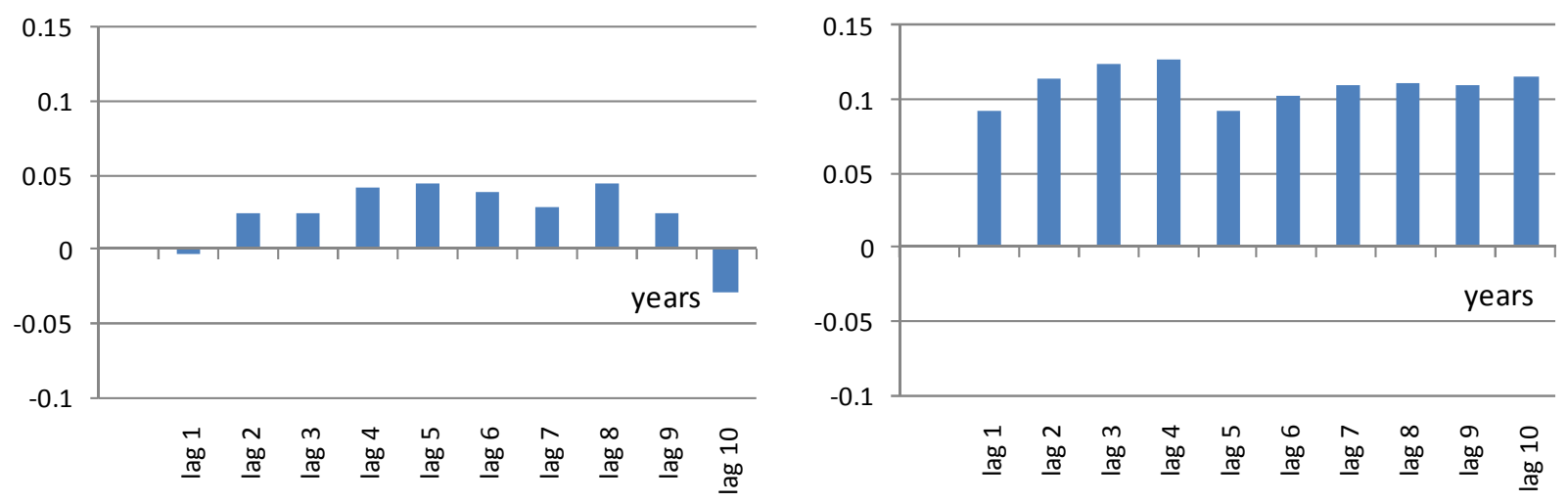

Employment protection legislation

Regular contracts

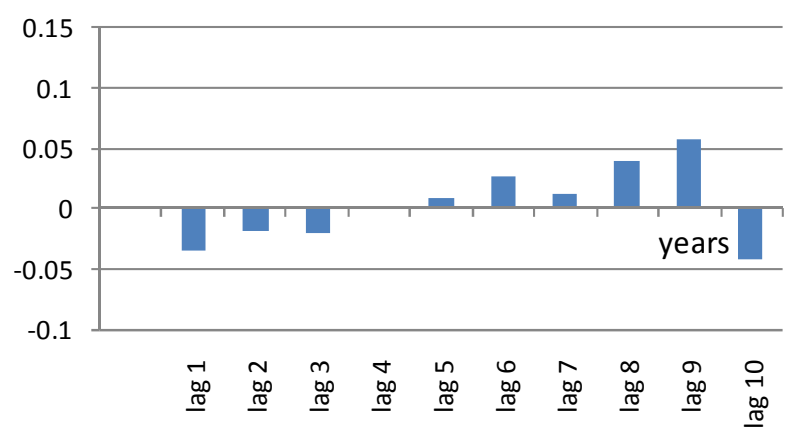

Employment protection legislation Temporary contracts

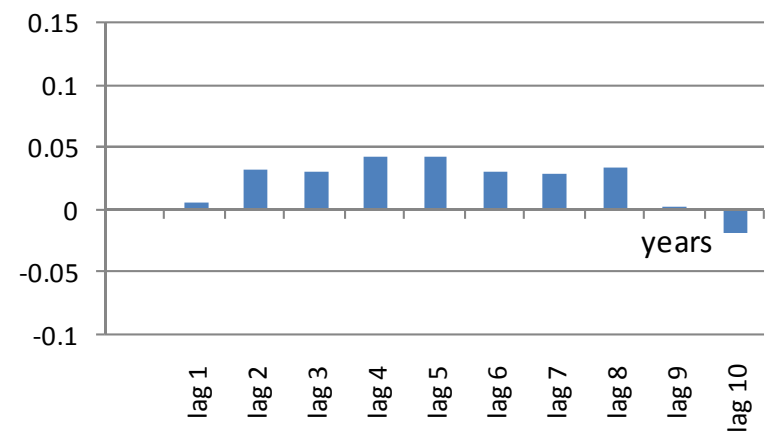

18. Overall, these results suggest that the impact of reforms is likely to be gradual and spread out over many years. Structural reforms can lead to a costly reallocation of resources, so that efficiency gains may take time to materialise. The following sections seek to provide additional information on the shape and speed of adjustment following selected labour market and tax reforms. 


\section{Labour and product market rigidities and adjustment speed}

19. A number of previous studies have suggested that interactions between different areas of structural reforms are crucial for their aggregate economic impact: long-term returns of implementing one reform would be enhanced when other reforms have already been implemented (Bassanini and Duval, 2006). Political economy considerations also indicate that injecting competition in product markets eases opposition and political resistance to labour market reforms, because product market reforms tend to lower the rents to be redistributed between unions and firms (Blanchard and Giavazzi, 2003). The objective of this section is to examine, whether policy complementarities may also affect the short-term adjustment to structural reforms, in particular to what extent product and labour market flexibility accelerates the passthrough of subsequent reforms.

\section{Employment adjustment costs have a moderate impact on real adjustment...}

20. To examine the impact of existing hiring and firing costs on the speed of adjustment to new labour market reforms, a one percentage-point income tax cut in the euro area was simulated using the DGE model presented in Box 2. In this model, hiring and firing costs are modelled through quadratic adjustment costs and provide firms with an incentive to smooth supply adjustment over time. ${ }^{10}$ These costs delay the transition of employment, production and consumption to the new steady state in the aftermath of structural reforms, but have no impact on the long-term effects of reforms. ${ }^{11}$

21. The introduction of adjustment costs to proxy nominal and real rigidities is standard in the DGE literature (e.g. Coenen et al., 2007; Grenouilleau et al., 2007; Campolmi and Faia, 2007; Moyen and Sahuc, 2005) but a number of specifications has been used. Quadratic cost specifications allow the quantity and price adjustments to be smoothed over time. Other functional forms, such as linear or even declining marginal adjustment costs, imply much faster and more abrupt adjustment paths. From this perspective, the quadratic specification of adjustment costs in this paper provides an upper bound for the adjustment duration and the impact of adjustment costs on the reform pass-through. In addition, micro level research gives information on asymmetric cost patterns, with either hiring or firing being more costly for firms depending on the regulatory circumstances. Such asymmetric behaviour is less relevant, however, in the context of this paper, because the simulations focus on adjustment after reforms that lead to higher employment and not on adjustment over the business cycle. ${ }^{12}$

22. Adjustment costs are calibrated using external information and imply costs of respectively $0.32 \%$ and $0.15 \%$ of GDP for a one percentage point change in employment in the euro area and the United States (Grenouilleau et al., 2007). Alternative functional forms and parameter values could generate substantially different transition paths (Cahuc and Zylberberg, 2004).

23. 24. Substituting lower US adjustment costs for higher euro area ones would accelerate adjustment towards the new equilibrium (Figure 3). Similar results are obtained for a cut in the benefit replacement ratio or in employer social security contributions (see Annex 4, Figures A.4.1 and A.4.2). Overall, the gain in production and consumption adjustment speed from lower employment costs seems nevertheless very modest, amounting to no more than two or three quarters. The differences are more

10. See Cahuc and Zylberberg (2004) for an excellent overview on labour adjustment costs.

11. An implication is that no long-term complementarity between reforms increasing flexibility and reforms increasing labour supply can be found in our simulations.

12. One major difference between our specification of employment adjustment costs and parts of the literature is that adjustment costs in our model are a function of firm specific output, rather than being a fixed costs or a function of aggregate production. Consequently, adjustment costs are an endogenous variable in the optimisation problem. 
marked with regard to inflation as cuts in the income tax rate, the benefit replacement rate or employer social security contributions all indirectly or directly reduce production costs. The cuts initially have a slightly deflationary effect, which in turn triggers an expansionary monetary reaction. Simulations suggest that if the euro area had US employment adjustment costs, price cuts could be more pronounced implying a more moderate decline in real wages in the transition process. Introducing heterogeneity in the form of liquidity-constrained consumers within the household sector, if anything, lowers the impact of employment adjustment costs on the adjustment process (see section 5). Changing the specification of employment adjustment cost and introducing linear rather than quadratic adjustment costs would not significantly modify the results.

Figure 3. Impact of a one-percentage point cut in the income tax rate

Percentage change compared to baseline, percentage points for inflation and interest rates

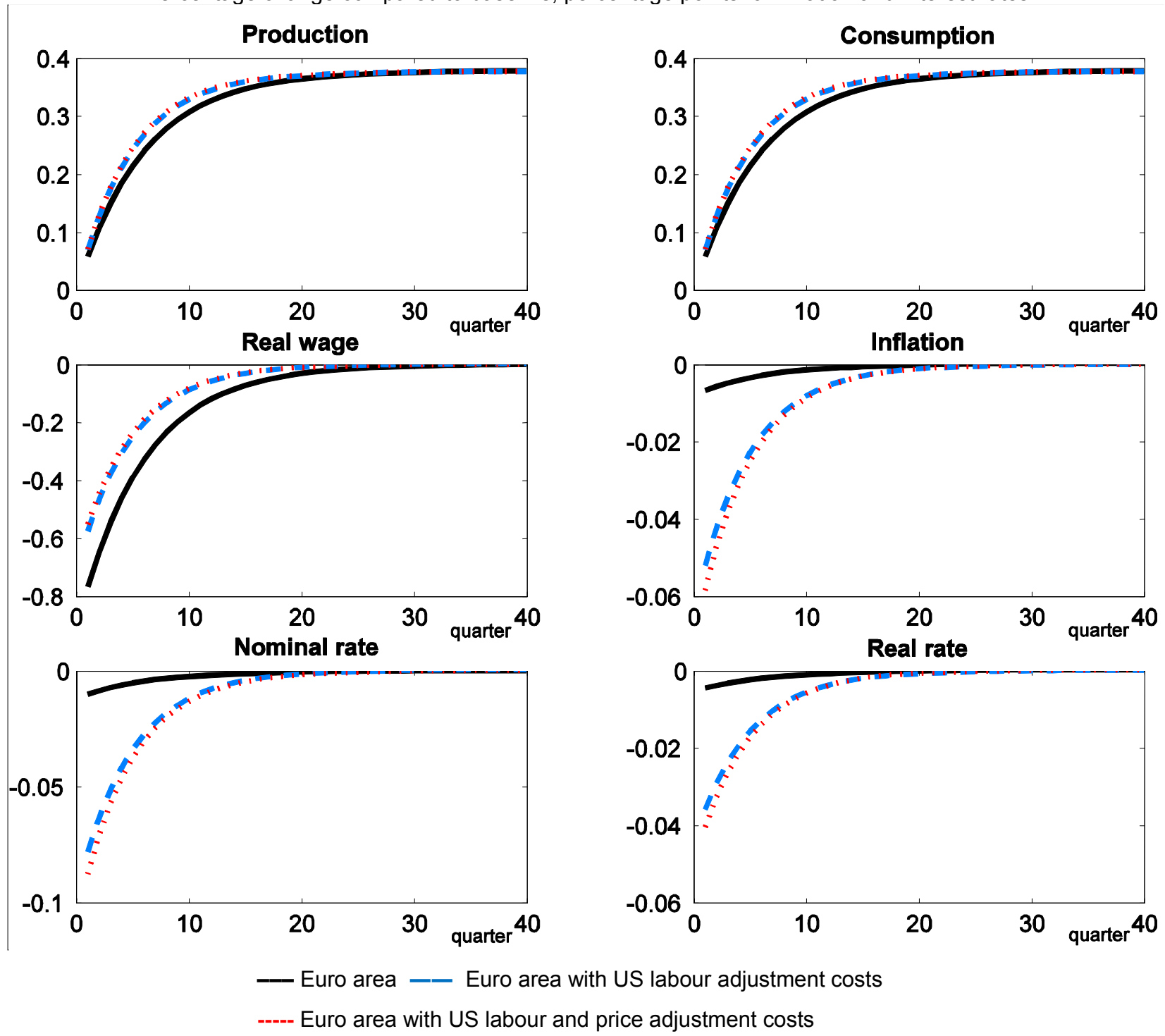

...while price adjustment costs almost exclusively affect nominal paths

25. Stronger competition and lower barriers to market entry can also quicken price adjustment. As for employment, price adjustment costs are modelled using a quadratic specification and calibrated using results from Grenouilleau et al. (2007). A one percentage-point price adjustment incurs adjustment costs of 
$0.11 \%$ of output in the euro area and $0.02 \%$ in the United States. The latter numbers are compatible with the degrees of price rigidity in the euro area and the United States documented in other empirical research (e.g. Bils and Klenow, 2004; Altissimo et al., 2006).

Figure 4. Impact of a one percentage-point income tax cut with nominal wage stickiness

Percentage change compared to baseline percentage points for inflation and interest rates
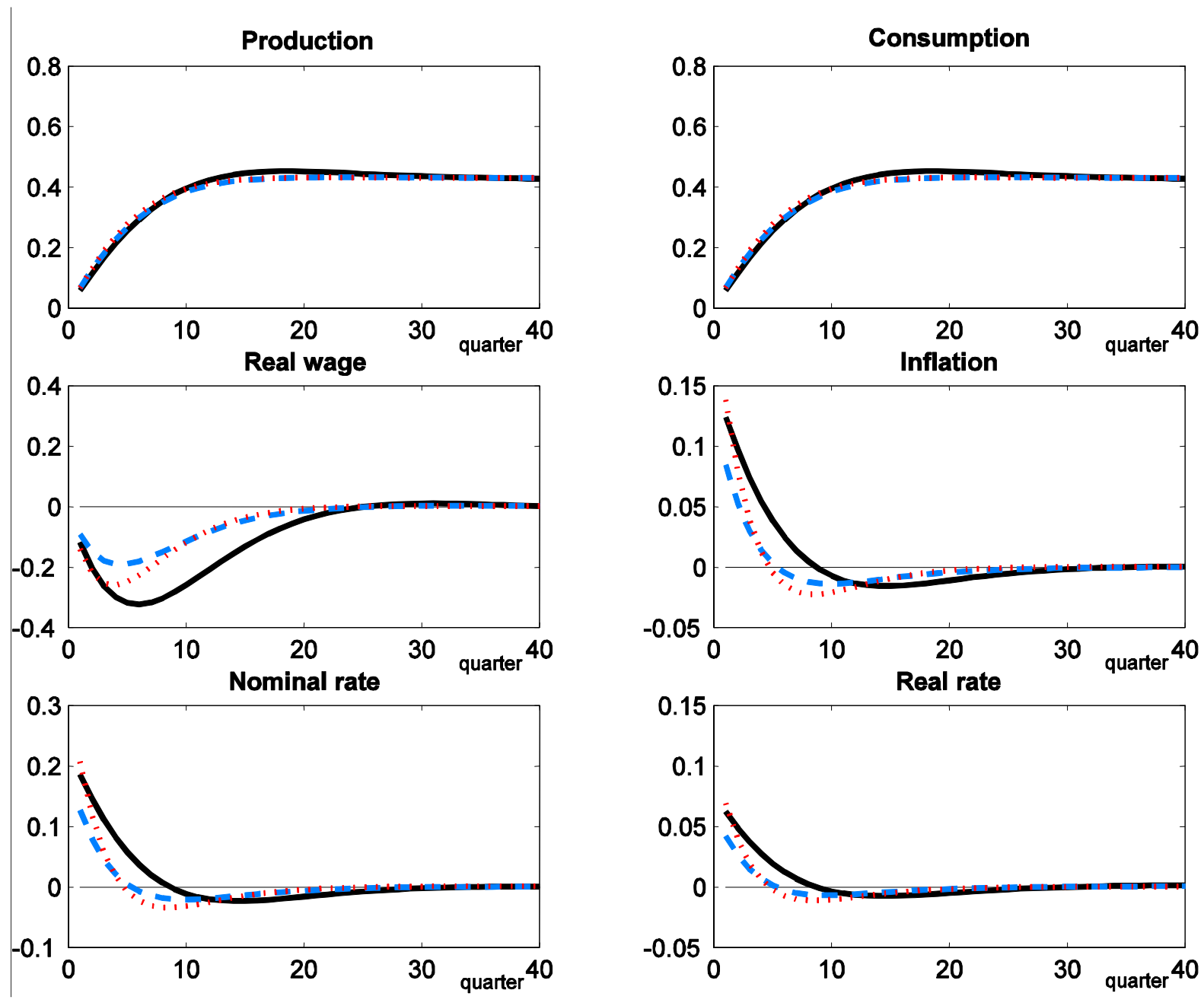

Euro area - - Euro area with US labour adjustment costs

---- Euro area US labour and price adjustment costs

25. DGE-based simulations suggest that lowering euro area price adjustment costs to US levels, while leaving employment adjustment costs at their initial level, would have no visible impact on the real variables' speed of adjustment (Figure 3). The differences in the transition paths of production, consumption and real wages for higher and lower price adjustment costs are negligible. Smaller price adjustment costs only generate a more marked initial price decline, which in turn leads to a modestly stronger monetary expansion. Price adjustment costs tend to play a more important role after temporary shocks, by dampening the initial amplitude of impulse responses and delaying the return to long-run equilibrium (Duval and Vogel, 2008).

26. This result also holds when nominal wage are rigid and adjust only progressively in a staggered setting framework (see Annex 3 for details). The impact of lower employment and price adjustment costs 
on real production and consumption is very small in this case (Figure 4). The transitory decline in real wages is more contained than under fully flexible wages. In contrast to Figure 3, this initially leads to a positive effect on inflation rates, triggering some monetary tightening instead of the easing that occurred under perfect wage flexibility.

Figure 5. Impact of a one percentage-point income tax cut in a search-and-matching framework

Percentage change compared to baseline percentage points for inflation and interest rates
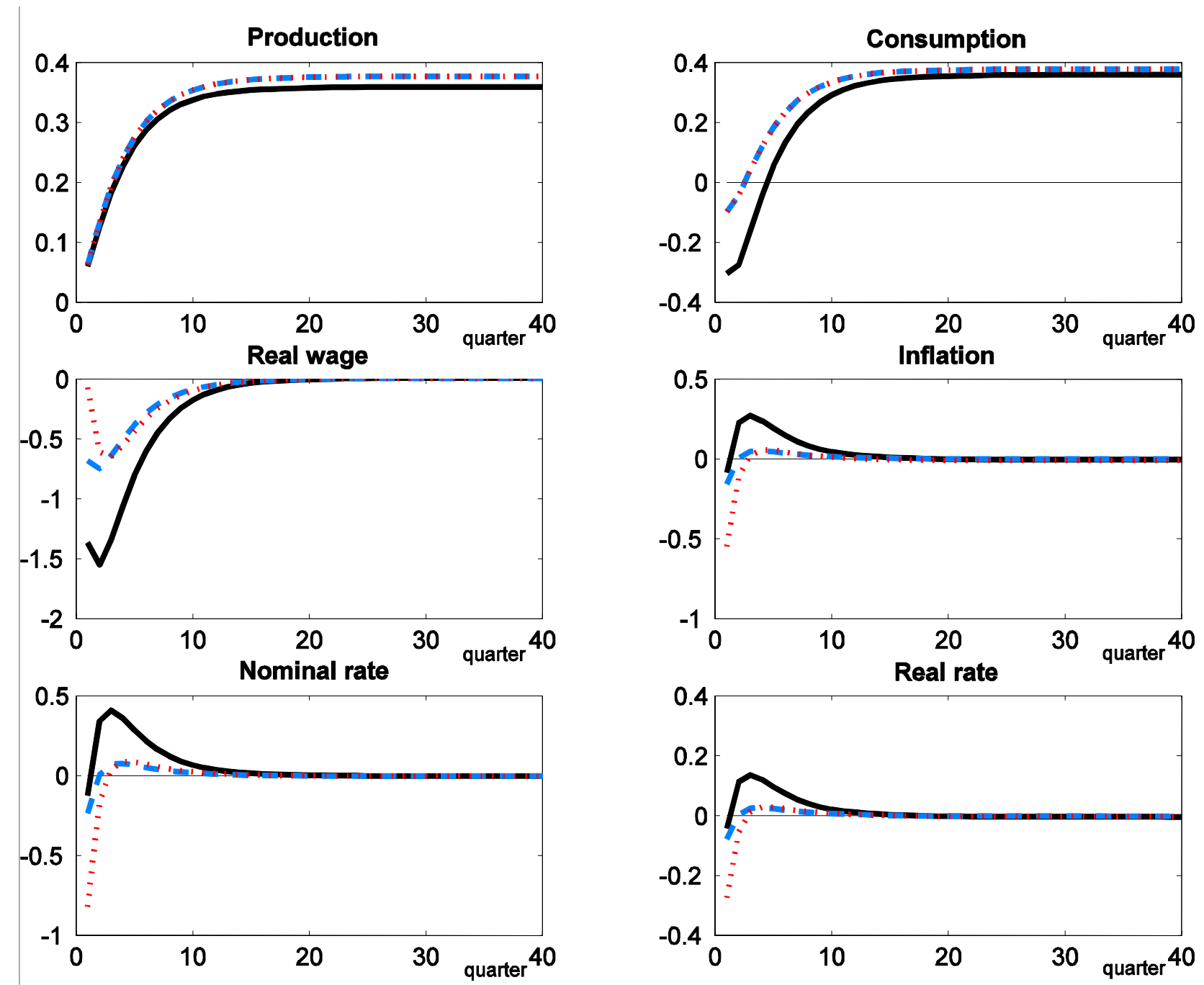

— Euro area - - Euro area with US labour adjustment costs

---- Euro area US labour and price adjustment costs

27. The adoption of a search-and-matching framework as an alternative model of the labour market also yields similar results concerning the limited role for adjustment costs in accelerating the economic adjustment to structural reforms (see Annex 3 for details). In this case, reduced employment adjustment costs would also have fairly limited effects on the adjustment speed of production and consumption, while the contribution of lower price adjustment costs is negligible. Differences are more pronounced with regard to price, real wage and interest rate patterns. Labour supply increases faster than labour demand in the presence of adjustment costs and frictional unemployment. The mismatch between labour supply and demand exerts downward pressure on real wages, production costs and prices. In addition, higher 
employment adjustment costs put additional pressure on real wages. ${ }^{13}$ As these effects are quantitatively strong, the economy will experience stronger monetary accommodation than in the simulation based on the standard DGE model.

28. The small impact of price and employment adjustment costs on the pace of adjustment is also confirmed by simulations using neo-Keynesian models for the United States and the euro area (see Annex 5). Indeed, in the absence of an endogenous monetary policy reaction, the euro area and the United States are found to adjust to a shock on the NAIRU at a similar pace at least in the short-term, even though the United States displays greater price and nominal wage flexibility than the euro area.

29. The impact of employment and price adjustment cost differentials between the euro area and the United States on the adjustment of real variables, especially output, to structural economic reforms is notably smaller than the heterogeneity in economic resilience to shocks found in Duval et al. (2007). Several factors help rationalising the difference in results. First, Duval et al. (2007) consider temporary shocks to the economy, while the reform scenarios in this paper correspond to permanent structural shifts. Indeed, the amplitude of output responses varies more across the alternative adjustment cost parameters if the DGE model in this paper is subject to temporary tax shocks. The initial amplitude of output responses increases with nominal and real flexibility consistent with Duval et al. (2007). Second, while Duval et al. (2007) consider an aggregate disturbance, fiscal reforms in the baseline model of this paper constitute pure supply-side shocks. There is evidence for the importance of price and employment adjustment cost differentials to vary across types of shocks. Price rigidity differentials, e.g., appear to have more pronounced effects on the output response under demand compared to productivity shocks (Grenouilleau et al.2007). Besides these two observations, increasing the set of frictions in the model could evidently also increase the heterogeneity of adjustment behaviour.

\section{Financial markets and adjustment speed}

30. Flexible and forward-looking financial markets can affect the adjustment speed to structural reforms. The United States deregulated many of its product and financial markets in the 1980s. Reforms have been more recent and less comprehensive within the euro area, even though major progress has been recently accomplished. Past reforms have increased the responsiveness of the economy to policy impulses and strengthened the direct impact of interest rates on financial decisions of both firms and households (Angeloni et al., 2003; Edey and Hviding, 1995; Mishkin, 2007).

31. Full access to credit allows firms to adjust their investment to their desired level and is thus likely to fasten adjustments to structural reform. In particular, deep venture capital markets facilitate the creation of firms and are found to partly explain differences in labour market performance between Anglo-Saxon economies and Continental Europe (Belke and Fehn, 2001; Acemoglu, 2001).

32. Financial sector reforms in the United States in the 1970s and 1980s are also estimated to have reduced the share of liquidity-constrained households (Sefton and In't Veld, 1999). The subsequent liberalisation of financial markets in the euro area is expected to have had similar effects, though it is hard to quantify its precise magnitude. The effect of easing households' liquidity constraints on adjustment speeds is a priori an empirical question. On the one hand, more households optimise their consumption

13. The higher adjustment costs result from adjustment costs relating to gross instead of net flows of labour in the search-and-matching extension. Each period a certain and fixed share of workers loses or quits a job for new positions or unemployment. Consequently, gross flows in and out of employment differ from net flows and are usually higher than the latter. Contrary to the baseline model, labour adjustment costs also affect the steady state production and consumption level in the search-and-matching framework. As there are separations in each period, positive adjustment costs will even accrue in the steady state, reducing the level of consumption and equilibrium employment. 
decisions and smooth income over time. On the other hand, habit persistence in these households' consumption behaviour is likely to slow the speed of adjustment.

33. This question can be examined by enriching the DGE model with a heterogeneous household sector. Some households have full access to financial markets, while others get limited or no access to financial markets and can only consume their disposable labour income at each period. A one percentagepoint income tax cut is then simulated under three alternatives: all households have full access to financial markets; $25 \%$ of the households are liquidity constrained; and $75 \%$ are liquidity constrained. Although the main differences are on the long term and reflect differences in utility functions between the two groups of households, changes to short-term adjustments can also be observed on inflation and monetary policy reaction (Figure 6). As the magnitude of the policy response varies with the share of liquidity-constrained households, the final effect on the pace of adjustment of real variables is negligible in the model. By omitting capital adjustments, these simulations may nevertheless underestimate the overall effect of liquidity constraints.

Figure 6. Impact of a one percentage-point income tax cut under alternative share of liquidity-constrained households in the euro area

Percentage change compared to baseline percentage points for inflation and interest rates

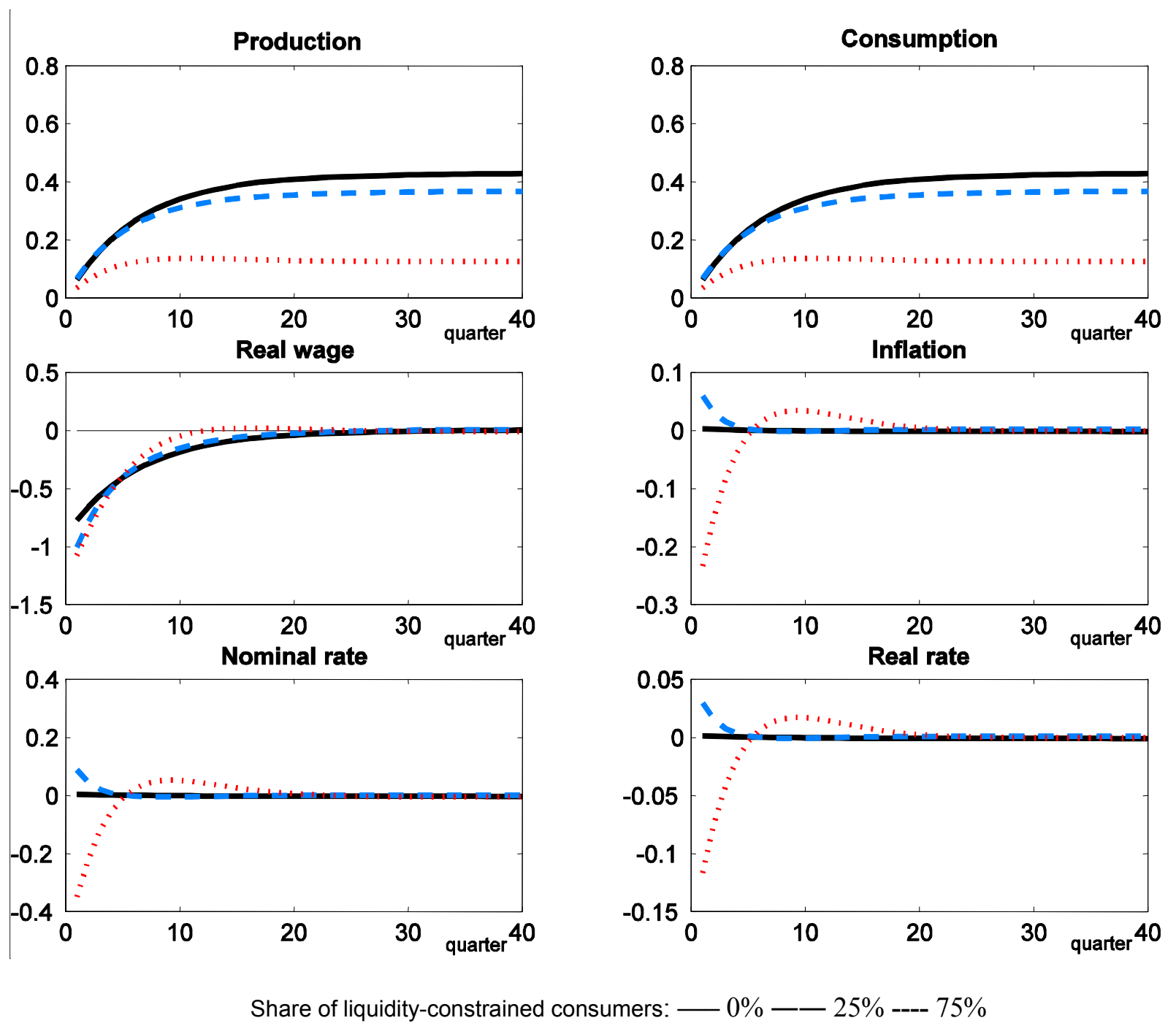


ECO/WKP(2008)55

\section{Interaction with monetary policy}

34. The implementation of labour market reforms has usually a significant macroeconomic impact in the short term and can call for a policy reaction. In turn, monetary policy decisions can affect the transition speed in the aftermath of structural reforms, though to a different degree across OECD countries, depending on the strength of the transmission channels and on the sensitivity of policy rates to output and inflation. Indeed, demand expansion reduces the transition costs of reforms and lowers unemployment stemming from the required restructuring of particular industries. From a political economy point of view, the ability and willingness of central bankers to accommodate structural reforms may reduce transitory costs and political opposition and thereby facilitate implementation.

35. The interaction between structural reforms and monetary policy can be illustrated by simulating a one percentage-point decline in the NAIRU, using the neo-Keynesian small models described in Box 1. In the absence of a monetary policy reaction, a decline in the NAIRU generates disinflationary effects, while output and unemployment gaps are building up. The introduction of monetary policy, in the form of a Taylor rule with equal weights on output and inflation, dampens the disinflationary effect and accelerates the move to the new long-term equilibrium (Figure 7 and Annex 5).

36. Expected gains from monetary policy reaction are estimated to be negligible for individual euro area economies. As the ECB focuses on aggregate euro area output and inflation, any monetary reaction to a reform implemented in an individual European country is improbable unless there is a coordinated effort to reform labour markets in a sufficient number of euro area countries. This holds for small but also large euro area economies. For instance, a domestic reform lowering the NAIRU by one percentage point in France, which accounts for about $20 \%$ of euro area GDP, would elicit almost no monetary policy reaction.

37. The contrast between the two sides of the Atlantic reflects differences in monetary transmission channels as modelled in the neo-Keynesian models. In line with previous empirical research (e.g. Angeloni et al., 2003a), demand components, especially business investment, are found to be more sensitive to real interest rates in the United States than in the euro area. Consequently, the United States would adjust much faster to the new steady state than the euro area in the presence of monetary policy reaction. ${ }^{14}$

38. Modifying the monetary policy reaction function can alter the pace of adjustment for the euro area. The impact of adopting a different monetary policy rule has been examined by simulating a cut in the NAIRU in the euro area under different policy reactions: a Taylor rule with equal weights on current inflation and the output gap; a Taylor rule with a stronger weight on inflation; and pure inflation targeting, with no weight on the output gap. Increasing the weight of inflation in the monetary reaction function appears to slow the adjustment in the very short term but to accelerate it thereafter. As a result, the economy reaches its long-term equilibrium much earlier, but with some overshooting (Figure 8). Even in the case of pure inflation targeting, the adjustment speed would nevertheless remain slower in the euro area than in the United States. Interest rate persistence, which implies that central banks are reluctant to move the policy rate too rapidly to limit output volatility, can slow the adjustment to structural reforms. However, both DGE and neo-Keynesian-based simulations suggest that interest rate persistence has to be very high (with a weight close to unity) to have visible effects on adjustment of real variables.

14. Because consumption equations have not been estimated over the same period in the United States and the euro area, the traditional result (e.g. Angeloni et al., 2003a, 2003b) that consumption is more sensitive to interest rates in the United States than in the euro area does not apply in this simulation. Hence, differences in the adjustment process between the United States and the euro area in the presence of monetary reaction may be underestimated. 
Figure 7. Effect of monetary policy on adjustment to a one percentage-point NAIRU decline

Effect on real GDP

(change compared to baseline)
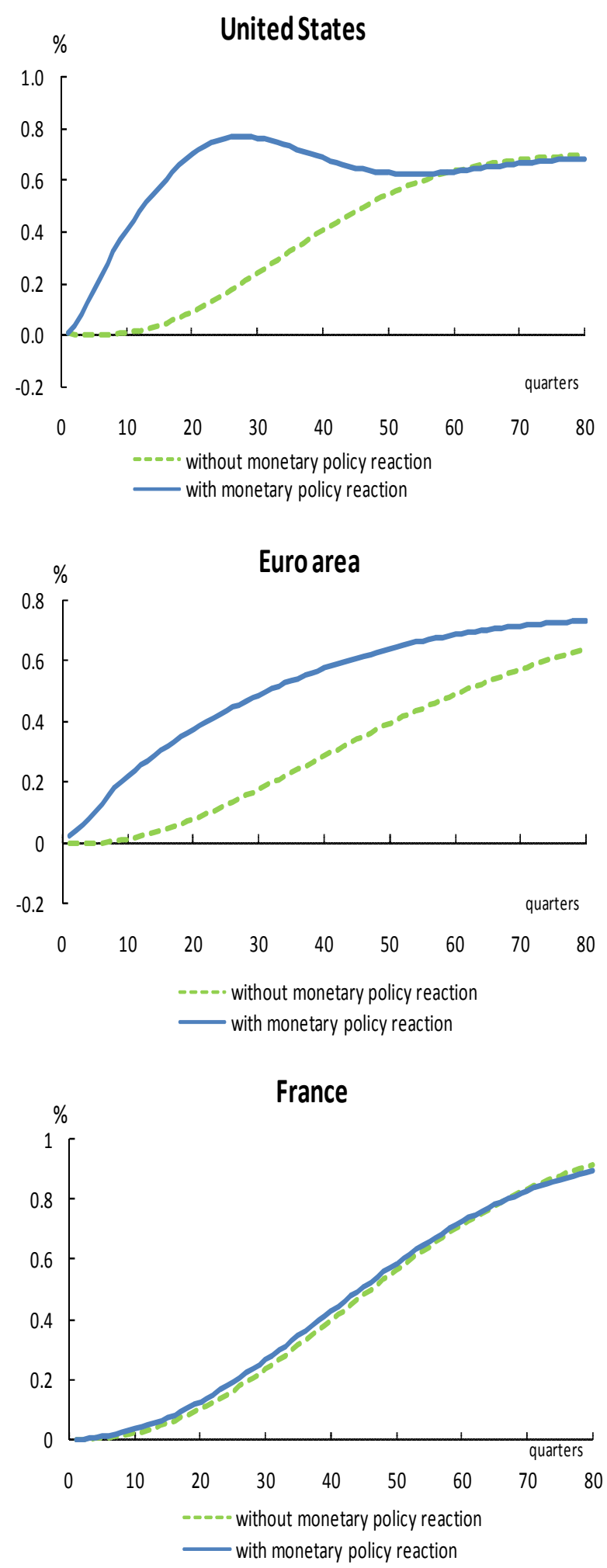

\section{Effect on inflation}

(percentage point change compared to baseline)

United States

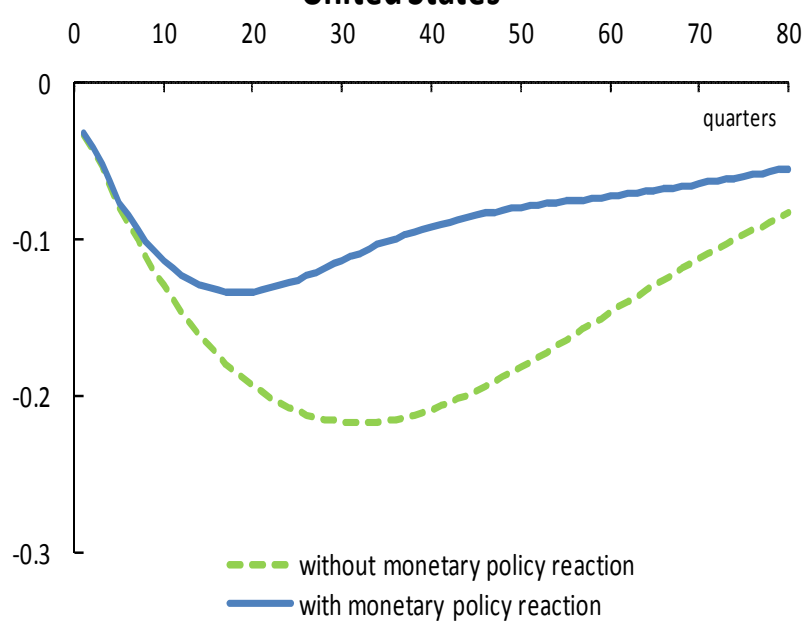

\section{Euro area}

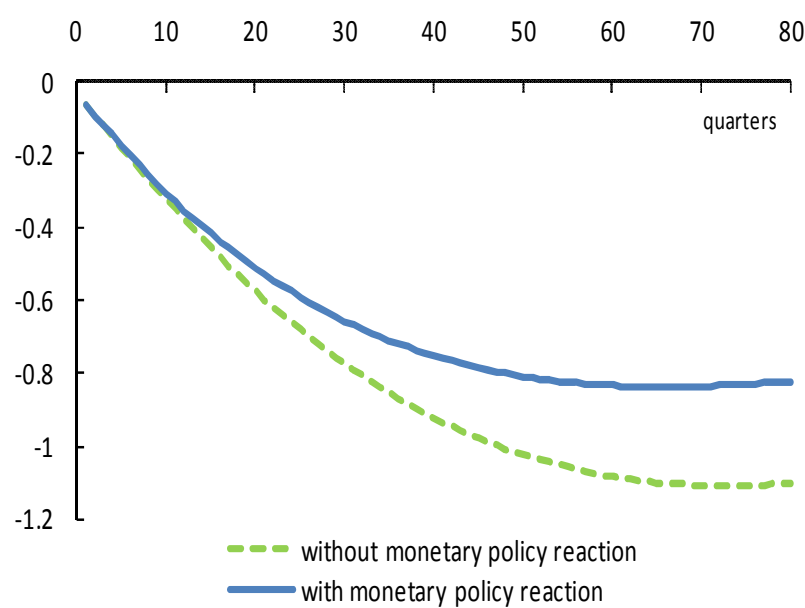

France

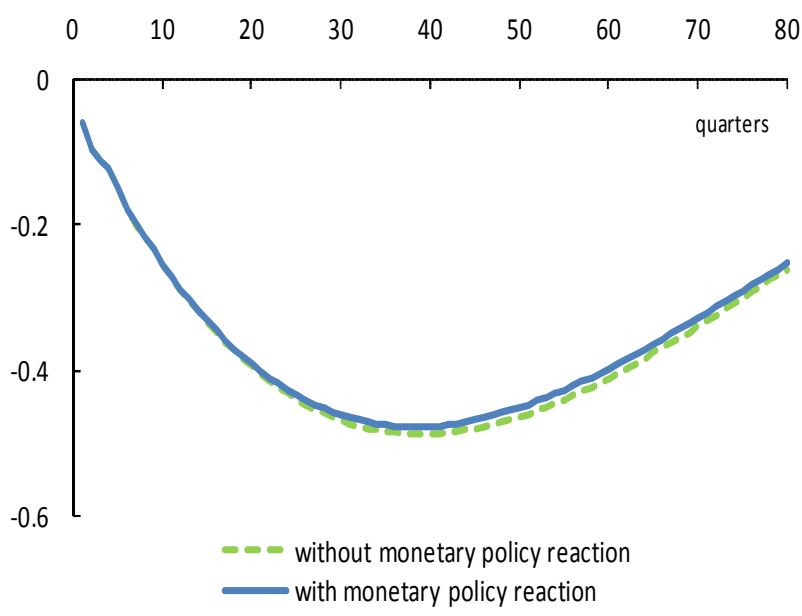


ECO/WKP(2008)55

Figure 8. Impact of a one percentage point decline in the NAIRU under alternative monetary policy reactions

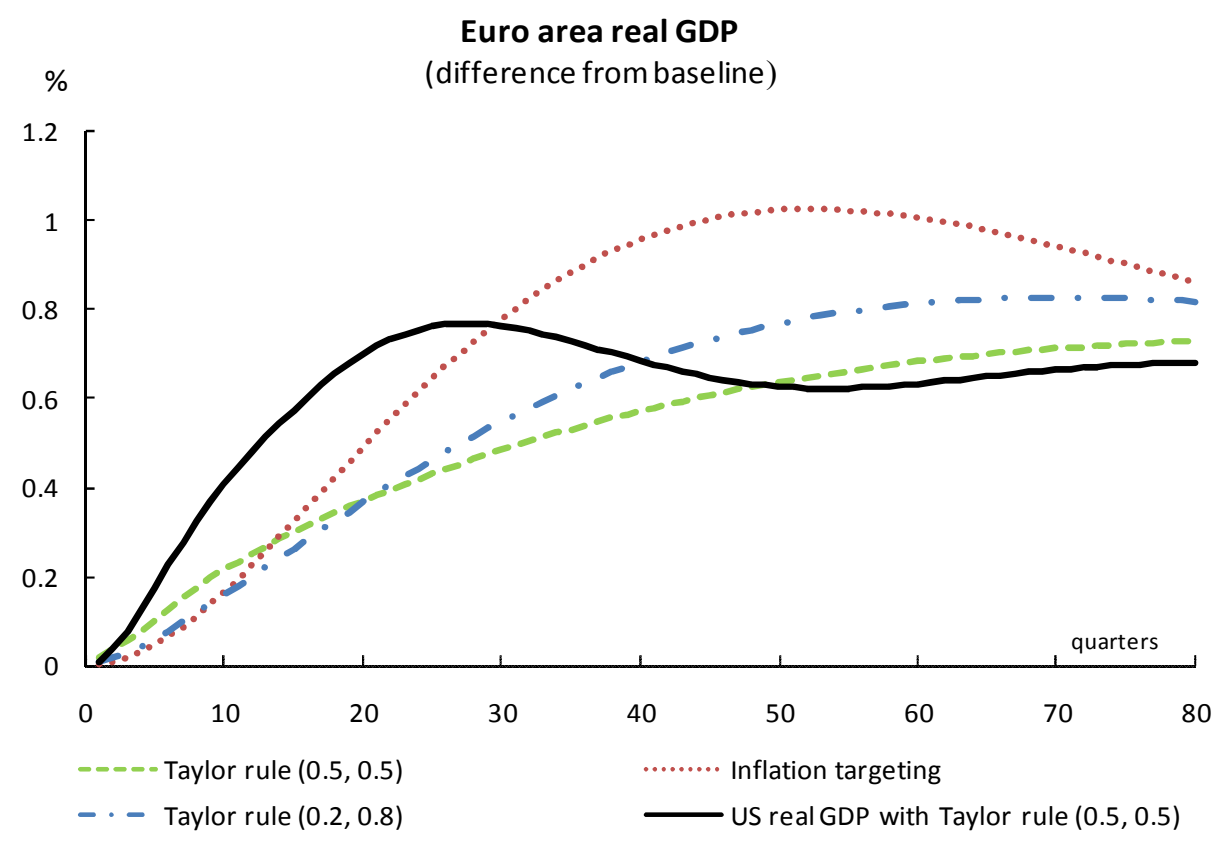

\section{Conclusion}

39. Economic adjustment to structural reforms is a gradual process. Drawing on various methodologies - descriptive analysis, macro-economic neo-Keynesian models, and a micro-founded dynamic general equilibrium model - this paper investigates the lag between the implementation of reforms and their economic effects, the impact of market rigidities and the role of monetary policy in the transition period.

40. The complementarities of these three different approaches motivate their combined use. The descriptive part seeks to draw conclusions from past OECD country experience in structural reforms. But, it strongly relies on data that often lack reliability and timeliness. Neo-Keynesian models have the advantage of using estimated behavioural equations for the euro area and the United States. However, the effect of some relevant institutions can be included only very indirectly - using off-model information and this approach is subject to the Lucas critique. Finally, the micro-founded DGE model illustrates the respective transmission channels of several types of structural reforms. Nevertheless, the introduction of employment and price adjustment costs as well as habit persistence in consumption in the model is insufficient to generate substantial cross-country heterogeneity in the adjustment speed. Methodological eclecticism is also a way to test the robustness of findings, where possible. In this regard, it is reassuring that the results of the paper for which robustness could be tested hold independently from the methodological approach adopted (e.g. limited role of price adjustment costs in the speed of adjustment to reforms).

41. The paper leaves ample room for extensions, in particular on the modelling side. First, the introduction of explicit households' accounts would allow simulating explicitly the impact of tax reforms in the neo-Keynesian framework. Second, one could examine whether monetary policy has become more or less important over time in accommodating structural reforms by examining whether the impact of interest rates on the main behavioural equations has changed in recent years. Third, the DGE model could be substantially refined by introducing additional frictions such as wage rigidities or capital adjustment costs, although this would considerably increase the complexity of the framework. In the same vein, the work could be extended to a framework with a multi-factor production function, and instead of calibrating the parameters Bayesian techniques could be applied to estimate DGE models for different countries. 


\section{BIBLIOGRAPHY}

Acemoglu, D. (2001), "Credit Market Imperfections and persistent unemployment", European Economic Review, No. 45, pp. 665-679.

Altissimo, F., M. Ehrmann and F. Smets (2006), "Inflation Persistence and Price-Setting Behaviour in the Euro Area: A Summary of the IPN Evidence", ECB Occasional Papers, No. 46.

Angeloni, I., A. Kashyap, B. Mojon and D. Terlizzese (2003a), "The Output Composition Puzzle: A Difference in the Monetary Transmission Mechanism in the Euro Area and United States", Journal of Money, Credit, and Banking, Vol. 35, No. 6, pp. 1265-1306

Angeloni, I., A. Kashyap and B. Mojon (eds., 2003b), Monetary Policy Transmission in the Euro Area, Cambridge University Press.

Amato, J. and T. Laubach (2003), "Rule-of-Thumb Behaviour and Monetary Policy", European Economic Review, Vol. 47, No. 5, pp. 791-831.

Arpaia, A., W. Roeger, J. Varga, J. in't Veld, I. Grolo and P. Wobst (2007), "Quantitative Assessment of Structural Reforms: Modelling the Lisbon Strategy", European Economy Economic Papers, No. 282.

Bassanini, A. and R. Duval (2006), "Employment Patterns in OECD Countries: Reassessing the Role of Policies and Institutions", OECD Economics Department Working Papers, No. 486.

Batini N., P. N'Diaye and A. Rebucci (2005), “The Domestic and Global Impact of Japan's Policies for Growth", IMF Working Papers, No. 05/209.

Bean, C. (1998), "The Interaction of Aggregate Demand Policies and Labour Market Reforms", Swedish Economic Policy Review, Vol. 5, No. 2, pp. 353-382.

Belot, M. and J. van Ours (2001), "Unemployment and Labour Market Institutions: An Empirical Analysis", Journal of the Japanese and International Economies, Vol. 15, No. 4, pp. 403-418.

Belke, A., and R. Fehn (2001), "Institutions and Structural Unemployment: Do Capital-Market Imperfections Matter?", CESifo Working Paper, No. 504.

Bils, M. and P. Klenow (2004), "Some Evidence on the Importance of Sticky Prices", Journal of Political Economy, Vol. 112, No. 5, pp. 947-984.

Blanchard, O. and J. Galí (2008), "Labour Markets and Monetary Policy: A New-Keynesian Model with Unemployment”, NBER Working Paper, No. 13897.

Blanchard, O. and F. Giavazzi (2003), "Macroeconomic Effects of Regulation and Deregulation on Goods and Labour Markets", Quarterly Journal of Economics, Vol. 118, No. 3, pp. 879-907. 
Cahuc, P. and A. Zylberberg (2004), Labour Economics, MIT Press, Cambridge, Mass.

Campolmi, A. and E. Faia (2006), "Cyclical Inflation Divergence and Different Labor Market Institutions in the EMU”, ECB Working Papers, No. 619.

Canzoneri, M., R. Cumby and B. Diba (2007): "The Cost of Nominal Rigidity in NNS Models", Journal of Money, Credit and Banking, Vol. 39, No. 7, pp. 1563-1586.

Christoffel, K. and T. Linzert (2005), "The Role of Real Wage Dynamics and Labor Market Frictions for Unemployment and Inflation Dynamics”, ECB Working Papers, No. 556.

Christopoulou, R. and P. Vermeulen (2008), "Markups in the Euro Area and the US over the Period 1981-2004", ECB Working Papers, No. 856.

Coenen, G., P. McAdam and R. Straub (2007), "Tax Reform and Labour-Market Performance in the Euro Area: A Simulation-Based Analysis Using the New Area-Wide Model", ECB Working Papers, No. 747.

Dreger, C., M. Artís, R. Moreno, R. Ramos and J. Suriñach (2007), "Study on the Feasibility of a Tool to Measure the Macroeconomic Impact of Structural Reforms", European Economy Economic Papers, No. 272.

Duval, R. and J. Elmeskov (2005), "The Effects of EMU on Structural Reforms in Labour and Product Markets", OECD Economics Department Working Papers, No. 438.

Duval, R., J. Elmeskov and L. Vogel (2007), "Structural Policies and Economic Resilience to Shocks", OECD Economics Department Working Papers, No. 567.

Duval, R. and L. Vogel (2008), "Oil Price Shocks, Rigidities and the Conduct of Monetary Policy: Some Lessons from a New Keynesian Perspective", OECD Economics Department Working Papers, No. 603.

Edey M. and K. Hviding (1995), “An Assessment of Financial Reforms in OECD Countries”, OECD Economics Department Working Papers, No. 154.

Erceg, Ch., D. Henderson and A. Levin (2000), "Optimal Monetary Policy with Staggered Wage and Price Contracts”, Journal of Monetary Economics, Vol. 46, No. 2, pp. 281-313.

Estevão, M. (2005), "Product Market Regulation and the Benefits of Wage Moderation", IMF Working Papers, No. 05/191.

Ernst, E., G. Gong, W. Semmler and L. Bukeviciute (2006), "Quantifying the Impact of Structural Reforms", ECB Working Papers, No. 666.

Everaert, L. and W. Schule (2006), "Structural Reforms in the Euro Area: Economic Impact and Role of Synchronisation across Markets and Countries", IMF Working Papers, No. 137.

Faia, E. (2006), "Optimal Monetary Policy Rules with Labor Market Frictions", ECB Working Papers, No. 698.

Freeman, R. (1998), "War of Models: Which Labour Market Institutions for the 21st Century?", Labour Economics, Vol. 5, No. 1, pp. 1-24. 
Fuhrer, J. (2000), "Habit Formation in Consumption and Its Implications for Monetary-Policy Models", American Economic Review, Vol. 90, No. 3, pp. 367-390.

Galí, J., D. Lopez-Salido and J. Vallés (2004), "Rule-of-Thumb Consumers and the Design of Interest Rate Rules", Journal of Money, Credit, and Banking, Vol. 36, No. 4, pp. 739-763.

Galí, J., D. López-Salido and J. Vallés (2007), "Understanding the Effects of Government Spending on Consumption", Journal of the European Economic Association, Vol. 5, No. 1, pp. 227-270.

Grenouilleau, D., M. Ratto and W. Roeger (2007), "Adjustment to Shocks: A Comparison between the Euro Area and the US Using Estimated DSGE Models", paper presented at the Workshop on Structural Reforms and Economic Resilience, OECD, Paris, 14 June.

Hamermesh, D. (1995), "Labour Demand and the Source of Adjustment Costs", Economic Journal, Vol. 105, No. 430, pp. 620-634.

Hunt, B. and D. Laxton (2004), "Some Simulation Properties of the Major Euro Area Economies in MULTIMOD”, Economic Modelling, Vol. 21, No. 5, pp. 759-783.

Inklaar, R. and M. Timmer (2006), "Resurgence of Employment Growth in the European Union: The Role of Cycles and Labour Market Reforms", Economics Letters, Vol. 91, No. 1, pp. 61-66.

Kilponen, J. and A. Ripatti (2006), "Labour and Product Market Reforms in General Equilibrium: Simulation Results Using a DGE Model of the Finnish Economy", Bank of Finland Research Discussion Papers, No. 5/2006.

Mishkin, F. (2007), "Housing and the Monetary Transmission Mechanism", NBER Working Papers, No. 13518.

Moyen, S. and J.-G. Sahuc (2005), "Incorporating Labour Market Frictions into an Optimising-Based Monetary Policy Model”, Economic Modelling, Vol. 22, No. 1, pp. 159-186.

Nicoletti, G. and S. Scarpetta (2005), "Product Market Reforms and Employment in OECD Countries", OECD Economics Department Working Paper, No. 472.

OECD (2007a), Employment Outlook, OECD, Paris.

OECD (2007b), Benefits and Wages, OECD, Paris.

OECD (2008), Going for Growth, OECD , Paris.

Rotemberg, J. (1982), "Monopolistic Price Adjustment and Aggregate Output", Review of Economic Studies, Vol. 49, No. 4, pp. 517-531.

Sahuc, J.-G. and F. Smets (2008), Differences in Interest Rate Policy at the ECB and the Fed: An Investigation with a Medium-Scale DSGE Model, Journal of Money, Credit and Banking, Vol. 40, No. 23, pp. 505-521.

Sefton, J. and J. In't Veld (1999), "Consumption and Wealth: An International Comparison", The Manchester School, Vol. 67, No. 4, pp. 525-544. 
Smets, F. and R. Wouters (2003), “An Estimated Dynamic Stochastic General Equilibrium Model of the Euro Area", Journal of the European Economic Association, Vol. 1, No. 5, pp. 1123-1175.

Smets, F. and R. Wouters (2005), "Comparing Shocks and Frictions in US and Euro Area Business Cycles: A Bayesian DSGE Approach", Journal of Applied Econometrics, Vol. 20, No. 2, pp. 161-183. 


\section{ANNEX 1. ADDITIONAL RESULTS FROM THE DESCRIPTIVE ANALYSIS}

Figure A.1. Structural unemployment and contributions of institutions in the European Union
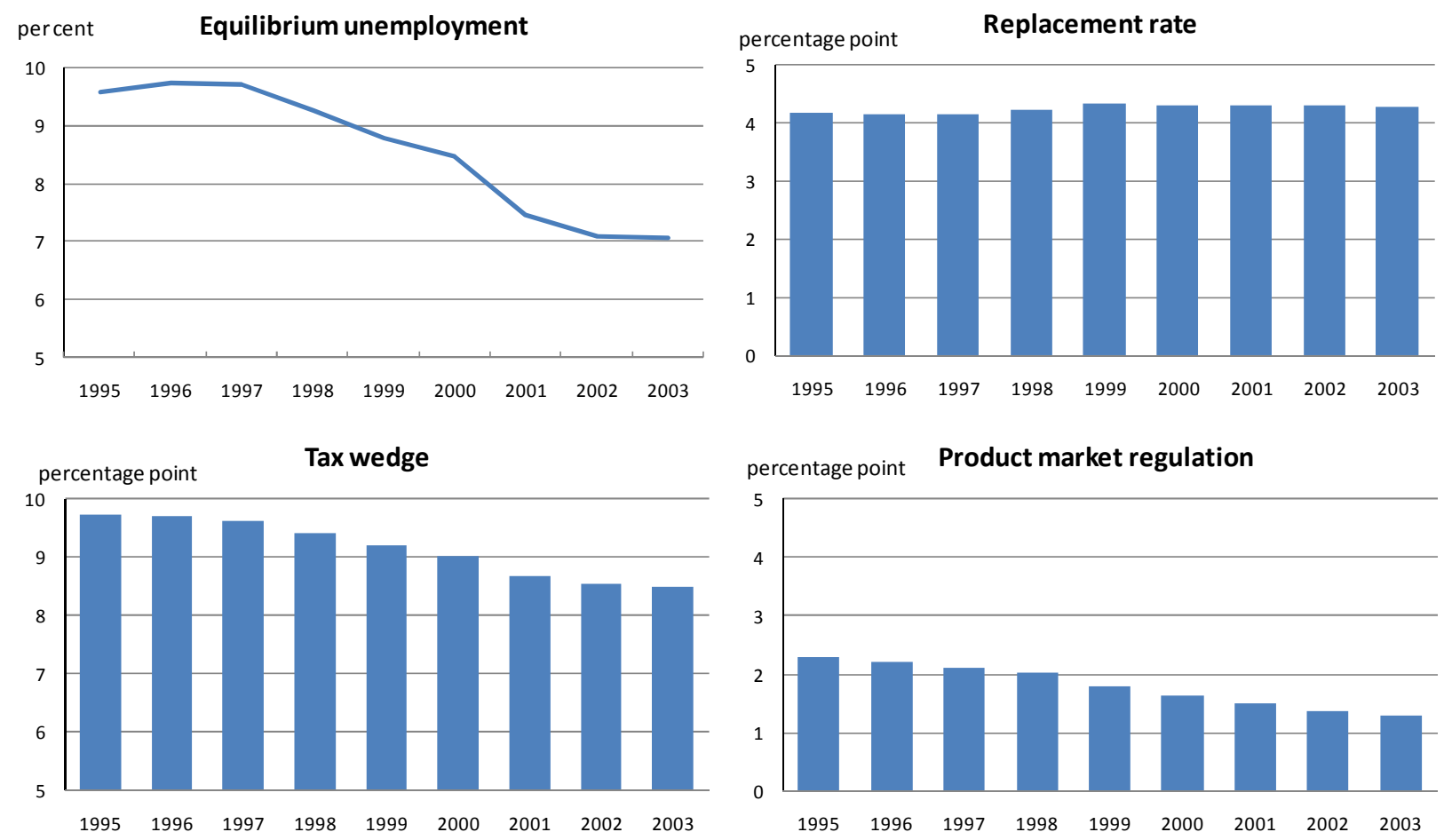
Figure A.2. Structural unemployment and contributions of institutions in the United States
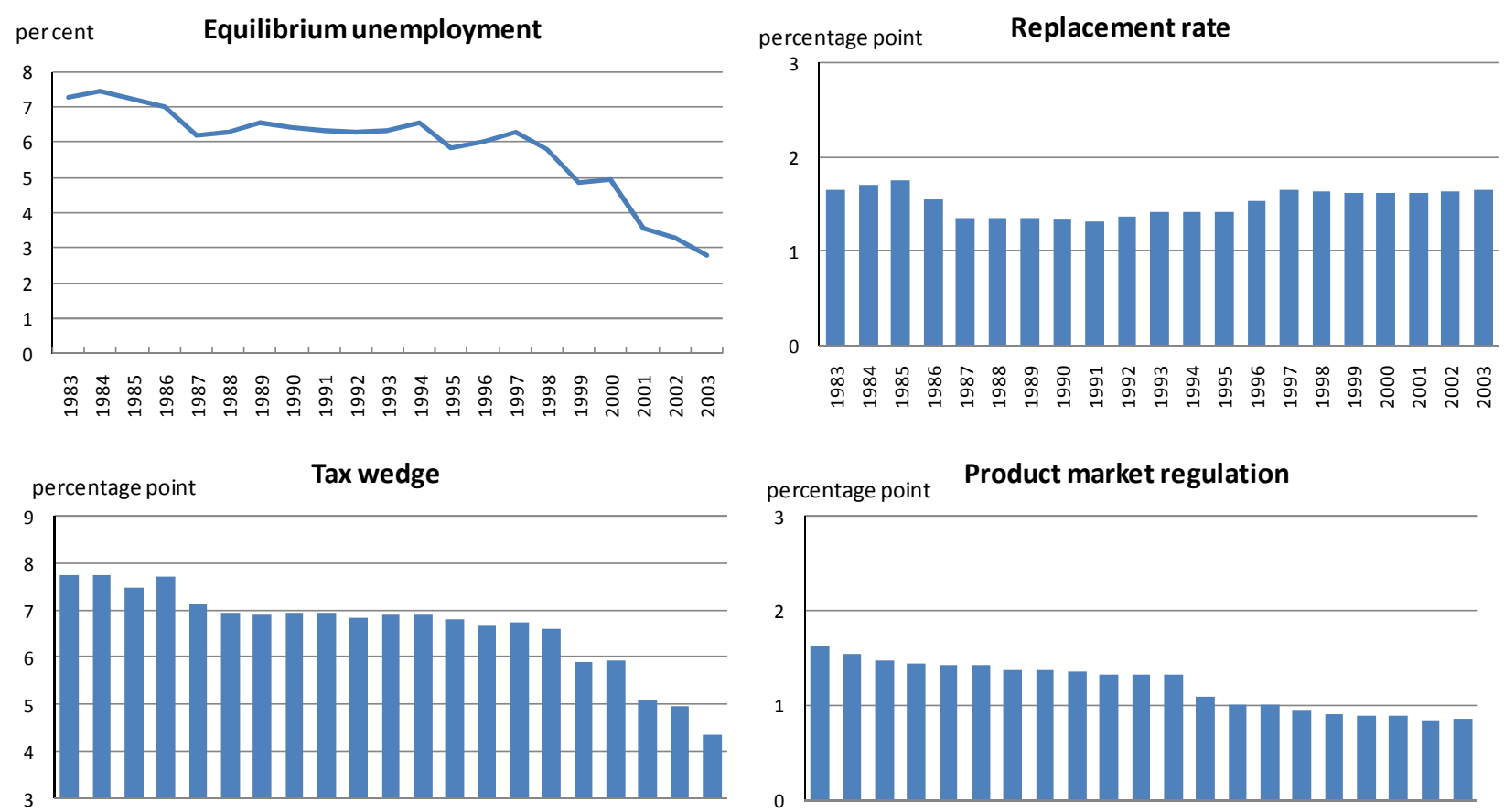

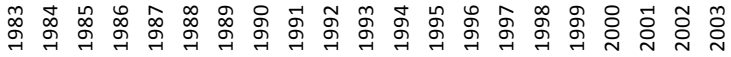

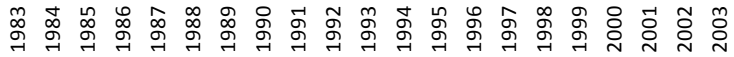

Figure A.3. Structural unemployment and the contribution of institutions in Japan

\section{percent Equilibrium unemployment}

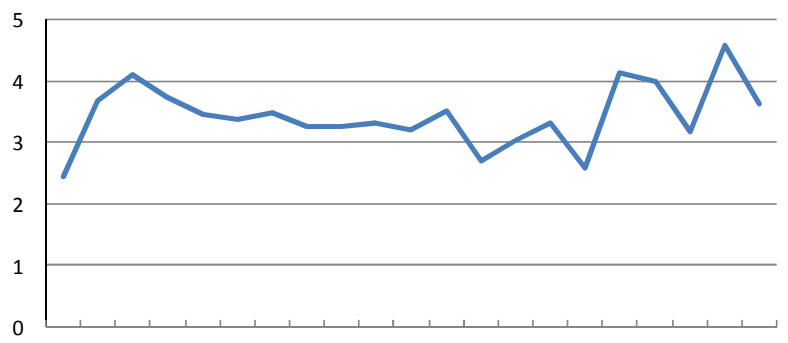

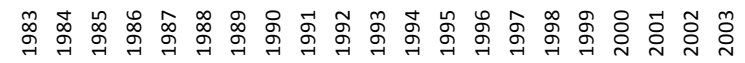

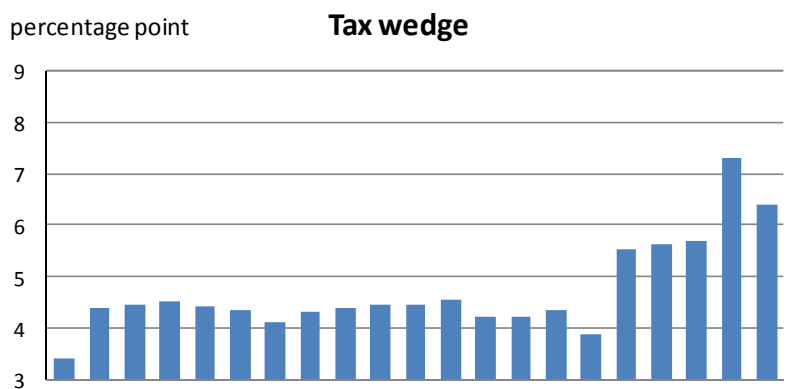

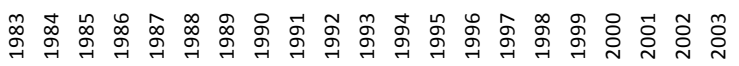

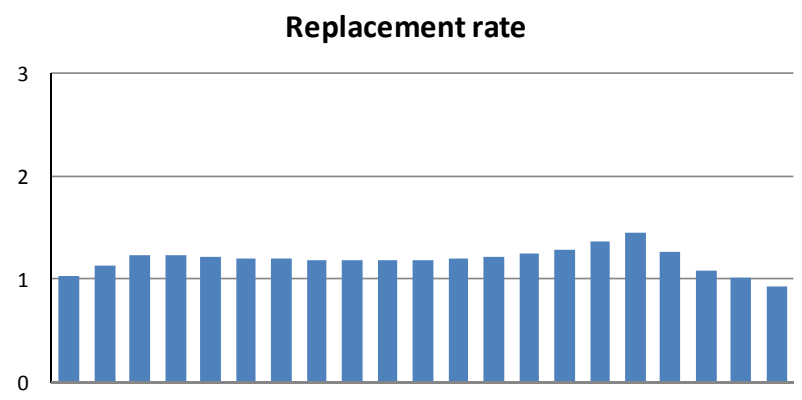

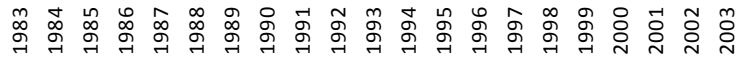

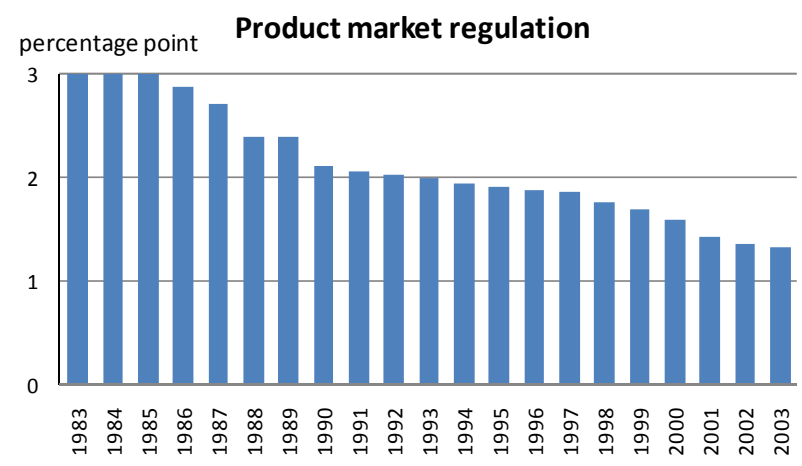




\section{ANNEX 2. MAIN EQUATIONS OF THE NEO-KEYNESIAN MODELS}

Equations are generally estimated in an error-correction form, using a general to specific approach. Only the main behavioural equations are reported in this annex. The complete text of the model is available upon request.

\begin{tabular}{ll}
\hline Keys to variables & \\
\hline $\mathrm{C}$ & private consumption \\
gap & output gap \\
$\mathrm{h}$ & hours \\
$\mathrm{h}^{*}$ & trend hours \\
$\mathrm{i}$ & investment \\
$\mathrm{ih}$ & housing investment \\
$\mathrm{n}$ & employment \\
$\mathrm{n}^{*}$ & potential employment \\
$\mathrm{p}$ & production prices \\
pcore & core consumer price \\
pih & price of housing \\
$\mathrm{pm}$ & import price all goods and services \\
$\mathrm{rs}$ & short-term real interest rate \\
$\mathrm{rl}$ & long-term real interest rate \\
$\mathrm{u}$ & unemployment rate \\
$\mathrm{ugap}$ & unemployment gap \\
$\mathrm{w}$ & wage \\
$\mathrm{y}^{\mathrm{d}}$ & household disposable income \\
$\mathrm{y}^{*}$ & potential output \\
\hline
\end{tabular}

\begin{tabular}{ll}
\hline Test & \\
\hline WHITE & White heteroskedasticity test \\
LM(2) & Breusch-Godfrey Serial Correlation LM Test - 2 lags \\
CHOW STABILITY & Chow Breakpoint Test: 2000Q1 \\
CHOW PREDICTIVE & Chow Forecast Test: Forecast from 2006Q4 to 2007Q2 \\
NORMALITY & Jarque-Bera Normality test \\
\hline
\end{tabular}




\begin{tabular}{|c|c|c|c|c|c|c|}
\hline \multirow[t]{2}{*}{ Consumption : c } & \multicolumn{2}{|c|}{ UNITED STATES } & \multicolumn{2}{|c|}{ EURO AREA } & \multicolumn{2}{|c|}{ FRANCE } \\
\hline & COEF. & TSTAT & COEF. & TSTAT & COEF. & TSTAT \\
\hline cst & -1.85 & -2.12 & -0.01 & -3.17 & 0.03 & 2.03 \\
\hline$\Delta y^{d}$ & 0.26 & 4.44 & 0.28 & 4.08 & & \\
\hline $\operatorname{mov}\left(\Delta y^{d}, 4\right)$ & & & & & 0.41 & 2.08 \\
\hline$c(-1)-y(-1)$ & -0.21 & -4.05 & -0.17 & -4.05 & -0.13 & -2.47 \\
\hline rs & & & -0.06 & -2.30 & & \\
\hline $\mathrm{rs}(-1)$ & -0.04 & -3.47 & & & & \\
\hline $\operatorname{mov}(r s, 4)$ & & & & & -0.001 & -2.69 \\
\hline$\Delta u$ & & & -0.01 & -4.31 & & \\
\hline u & & & & & -0.001 & -1.47 \\
\hline Estimation period & $1980 Q$ & 07Q2 & 1991Q & 007Q2 & $1985 Q$ & 007Q2 \\
\hline SE & 0.50 & & 0.00 & & 0.01 & \\
\hline$R^{2}$ & 0.30 & & 0.40 & & 0.19 & \\
\hline DW & 1.78 & & 2.14 & & 2.06 & \\
\hline RESET & 0.00 & & 0.00 & & 0.14 & \\
\hline WHITE & 0.00 & & 0.00 & & 0.14 & \\
\hline $\operatorname{LM}(2)$ & 0.05 & & 0.41 & & 0.46 & \\
\hline CHOW STABILITY & 0.41 & & 0.08 & & 0.02 & \\
\hline CHOW PREDICTIVE & 0.99 & & 0.83 & & 0.61 & \\
\hline NORMALITY & 0.68 & & 0.01 & & 0.08 & \\
\hline \multicolumn{7}{|c|}{ Note: MOV means moving average } \\
\hline \multirow[t]{2}{*}{ Business investment : $\Delta \mathbf{i}$} & \multicolumn{2}{|c|}{ UNITED STATES } & \multicolumn{2}{|c|}{ EURO AREA } & \multicolumn{2}{|c|}{ FRANCE } \\
\hline & COEF. & TSTAT & COEF. & TSTAT & COEF. & TSTAT \\
\hline Cst & -10.56 & -3.51 & -38.00 & -5.81 & -19.35 & -3.68 \\
\hline $\operatorname{mov}(\Delta \mathrm{i}(-2), 2)$ & 0.32 & 2.75 & & & & \\
\hline$\Delta \mathrm{y}$ & 1.60 & 6.15 & & & 2.16 & 9.16 \\
\hline $\operatorname{mov}(\Delta y(-1), 7)$ & 1.93 & 2.68 & & & 2.09 & 4.77 \\
\hline $\operatorname{mov}(\Delta y(-1), 2)$ & & & 2.01 & 5.16 & & \\
\hline$i(-1)-y(-1)$ & -0.05 & -3.55 & -0.19 & -5.84 & -0.08 & -3.62 \\
\hline $\operatorname{mov}(r l(-1), 4)$ & -0.64 & -4.58 & & & -0.15 & -1.76 \\
\hline $\operatorname{mov}(\mathrm{rl}(-1), 6)$ & & & -0.52 & -5.96 & & \\
\hline Estimation period & \multicolumn{2}{|c|}{ 982Q1 2007Q2 } & \multicolumn{2}{|c|}{ 1992Q3 2007Q2 } & \multicolumn{2}{|c|}{ 1982Q1 2007Q2 } \\
\hline SE & \multicolumn{2}{|l|}{1.50} & \multicolumn{2}{|l|}{0.93} & \multicolumn{2}{|l|}{0.93} \\
\hline $\mathrm{R}^{2}$ & \multicolumn{2}{|l|}{0.55} & \multicolumn{2}{|l|}{0.64} & \multicolumn{2}{|l|}{0.65} \\
\hline DW & \multicolumn{2}{|l|}{1.94} & \multicolumn{2}{|l|}{2.69} & \multicolumn{2}{|l|}{2.06} \\
\hline RESET & \multicolumn{2}{|l|}{0.78} & \multicolumn{2}{|l|}{0.38} & \multicolumn{2}{|l|}{0.70} \\
\hline WHITE & \multicolumn{2}{|l|}{0.55} & 0.61 & & 0.51 & \\
\hline LM(2) & 0.88 & & 0.02 & & 0.14 & \\
\hline CHOW STABILITY & 0.13 & & 0.12 & & 0.61 & \\
\hline CHOW PREDICTIVE & 0.87 & & 0.79 & & 0.58 & \\
\hline NORMALITY & 0.83 & & 0.67 & & 0.27 & \\
\hline
\end{tabular}




\begin{tabular}{|c|c|c|c|c|}
\hline \multirow[t]{2}{*}{ Housing investment: $\Delta$ ih } & \multicolumn{2}{|c|}{ UNITED STATES } & \multicolumn{2}{|c|}{ FRANCE } \\
\hline & COEF. & TSTAT & COEF. & TSTAT \\
\hline cst & -38.46 & -3.92 & -16.88 & -1.84 \\
\hline$\Delta \operatorname{ih}(-1)$ & 0.70 & 8.31 & & \\
\hline$\Delta \mathrm{y}^{\mathrm{d}}$ & 0.90 & 3.42 & & \\
\hline$\Delta y^{d}(-1)$ & & & 0.31 & 1.44 \\
\hline $\operatorname{in}(-1)-y^{d}(-1)$ & -0.14 & -4.00 & -0.07 & -2.10 \\
\hline$(\mathrm{rl}+\mathrm{rl}(-1)) / 2$ & -0.51 & -2.32 & -0.36 & -3.42 \\
\hline$\Delta \mathrm{pih}(-1)$ & & & -0.33 & -1.55 \\
\hline $\operatorname{mov}(\Delta \operatorname{pih}(-1), 2)$ & 0.86 & 1.56 & & \\
\hline Estimation period & $1990 Q$ & 2007Q2 & $1990 Q$ & 007Q2 \\
\hline SE & 1.82 & & 1.30 & \\
\hline $\mathrm{R}^{2}$ & 0.57 & & 0.32 & \\
\hline DW & 2.02 & & 1.95 & \\
\hline RESET & 0.00 & & 0.96 & \\
\hline WHITE & 0.09 & & 0.62 & \\
\hline $\mathrm{LM}(2)$ & 0.64 & & 0.99 & \\
\hline CHOW STABILITY & 0.02 & & 0.22 & \\
\hline CHOW PREDICTIVE & 0.05 & & 0.77 & \\
\hline NORMALITY & 0.90 & & 0.15 & \\
\hline
\end{tabular}

\begin{tabular}{lcccccc}
\hline Employment equation : $\Delta(\mathbf{n}-\mathbf{h})$ & \multicolumn{2}{c}{ UNITED STATES } & \multicolumn{2}{c}{ EURO AREA } & \multicolumn{2}{c}{ FRANCE } \\
& COEF. & TSTAT & COEF. & TSTAT & COEF. & TSTAT \\
\hline & & & & & & \\
cst & 0.28 & 2.1 & 0.42 & 1.78 & 0.07 & 2.69 \\
$\Delta(\mathrm{n}-\mathrm{h})$ & 0.1 & 1.19 & 0.63 & 8.24 & 0.53 & 5.47 \\
$\Delta(\mathrm{n}(-1)-\mathrm{h}(-1))$ & & & & & 0.33 & 2.96 \\
$\Delta(\mathrm{n}(-2)-\mathrm{h}(-2))$ & 0.19 & 2.7 & & & -0.31 & -3.51 \\
$\Delta \mathrm{y}$ & 0.3 & 4.6 & 0.2 & 4.35 & 0.18 & 3.39 \\
$\Delta \mathrm{y}(-1)$ & 0.19 & 2.73 & & & & \\
$\Delta(\mathrm{w}-\mathrm{p})$ & & & -0.16 & -3.54 & -0.18 & -3.92 \\
mov $(\Delta(\mathrm{w}-\mathrm{p}), 4)$ & -0.29 & -3.59 & & & & \\
$\mathrm{n}(-1)-\mathrm{h}(-1)-\mathrm{y}(-1)+(\mathrm{w}(-1)-\mathrm{p}(-1))$ & -0.04 & -2.1 & -0.006 & -1.79 & -0.01 & -2.69 \\
& & & & & & \\
Estimation period & $1990 Q 12007 Q 2$ & $1991 \mathrm{Q} 12007 Q 2$ & $1990 \mathrm{2} 12007 \mathrm{2} 2$ \\
$\mathrm{SE}$ & 0.25 & & 0.13 & & 0.18 & \\
$\mathrm{R}^{2}$ & 0.69 & & 0.84 & & 0.74 & \\
DW & 1.62 & & 2.38 & & 1.99 & \\
\hline
\end{tabular}




\begin{tabular}{|c|c|c|c|c|c|c|}
\hline \multirow[t]{2}{*}{ Phillips curve: $\Delta \Delta$ pcore } & \multicolumn{2}{|c|}{ UNITED STATES } & \multicolumn{2}{|c|}{ EURO AREA } & \multicolumn{2}{|c|}{ FRANCE } \\
\hline & COEF. & TSTAT & COEF. & TSTAT & COEF. & TSTAT \\
\hline cst & 0.09 & 2.54 & 0.02 & 0.85 & 0.01 & 0.24 \\
\hline$\Delta \Delta$ pcore $(-1)$ & -0.63 & -6.45 & -0.48 & -3.57 & -0.27 & -2.92 \\
\hline$\Delta \Delta$ pcore $(-2)$ & -0.43 & -3.99 & -0.25 & -1.71 & -0.44 & -5.30 \\
\hline$\Delta \Delta$ pcore $(-3)$ & -0.18 & -2.00 & -0.23 & -1.70 & -0.33 & -3.66 \\
\hline ugap & -0.03 & -1.85 & -0.06 & -2.94 & -0.06 & -1.70 \\
\hline$\omega^{*} \Delta \Delta \mathrm{pm}(-1)$ & 0.24 & 1.16 & & & & \\
\hline$\Delta$ pcore $(-1)-\Delta w(-1)$ & -0.15 & -3.19 & -0.02 & $(c, p=0.22)$ & -0.10 & -2.81 \\
\hline Sacrifice ratio & -4.3 & & -2.0 & & -2.2 & \\
\hline Estimation period & 1981Q & $2007 Q 2$ & $1992 Q$ & $12007 Q 2$ & 19810 & 007Q2 \\
\hline SE & 0.16 & & 0.11 & & 0.26 & \\
\hline $\mathrm{R}^{2}$ & 0.51 & & 0.23 & & 0.33 & \\
\hline DW & 1.82 & & 1.86 & & 2.10 & \\
\hline RESET & 0.13 & & 0.49 & & 0.01 & \\
\hline WHITE & 0.04 & & 0.87 & & 0.00 & \\
\hline $\operatorname{LM}(2)$ & 0.04 & & 0.17 & & 0.05 & \\
\hline CHOW STABILITY & 0.41 & & 0.45 & & 0.82 & \\
\hline CHOW PREDICTIVE & 0.36 & & 0.21 & & 0.89 & \\
\hline NORMALITY & 0.87 & & 0.90 & & 0.00 & \\
\hline \multirow[t]{2}{*}{ Wage : $\Delta \mathbf{w}$} & \multicolumn{2}{|c|}{ UNITED STATES } & \multicolumn{2}{|c|}{ EURO AREA } & \multicolumn{2}{|c|}{ FRANCE } \\
\hline & COEF. & TSTAT & COEF. & TSTAT & COEF. & TSTAT \\
\hline cst & -0.01 & -0.99 & & & & \\
\hline$\Delta \mathrm{w}(-1)$ & -0.22 & -3.28 & & & & \\
\hline$\Delta p$ & 1.00 & c & 1.00 & c & 1.00 & c \\
\hline$w(-1)-p(-1)-n^{*}(-1)-y^{*}(-1)$ & -0.04 & -1.43 & -0.003 & -2.78 & -0.02 & -2.81 \\
\hline$\Delta$ ugap & 0.00 & -1.43 & & & & \\
\hline mov (ugap, 2) & & & -0.002 & -2.91 & -0.001 & -2.18 \\
\hline \multicolumn{7}{|l|}{ mov (ugap, 4) } \\
\hline Estimation period & \multicolumn{2}{|c|}{ 1980Q4 2007Q2 } & \multicolumn{2}{|c|}{ 1991Q2 2007Q2 } & \multicolumn{2}{|c|}{ 1980Q2 2007Q2 } \\
\hline SE & \multicolumn{2}{|c|}{0.01} & \multicolumn{2}{|c|}{0.00} & \multicolumn{2}{|c|}{0.00} \\
\hline $\mathrm{R}^{2}$ & \multicolumn{2}{|l|}{0.61} & \multicolumn{2}{|l|}{0.58} & \multicolumn{2}{|l|}{0.75} \\
\hline DW & \multicolumn{2}{|l|}{1.43} & \multicolumn{2}{|l|}{1.81} & \multicolumn{2}{|l|}{1.97} \\
\hline WHITE & \multicolumn{2}{|l|}{0.14} & \multicolumn{2}{|l|}{0.00} & \multicolumn{2}{|l|}{0.00} \\
\hline $\operatorname{LM}(2)$ & \multicolumn{2}{|l|}{0.00} & \multicolumn{2}{|l|}{0.71} & \multicolumn{2}{|l|}{0.95} \\
\hline CHOW STABILITY & 0.67 & & 0.00 & & 0.00 & \\
\hline CHOW PREDICTIVE & 0.06 & & 0.34 & & 0.22 & \\
\hline NORMALITY & 0.11 & & 0.02 & & 0.78 & \\
\hline
\end{tabular}


ECO/WKP(2008)55

\begin{tabular}{|c|c|c|c|c|c|c|}
\hline \multirow[t]{2}{*}{ Producer price : $\Delta \mathbf{p}$} & \multicolumn{2}{|c|}{ UNITED STATES } & \multicolumn{2}{|c|}{ EURO AREA } & \multicolumn{2}{|c|}{ FRANCE } \\
\hline & COEF. & TSTAT & COEF. & TSTAT & COEF. & TSTAT \\
\hline cst & -0.01 & -0.36 & 0.20 & 3.39 & 0.07 & 1.78 \\
\hline$\Delta \mathrm{p}(-1)$ & 0.50 & 5.46 & & & & \\
\hline$\Delta \mathrm{p}(-2)$ & 0.16 & 1.55 & & & & \\
\hline$\Delta \mathrm{p}(-3)$ & 0.34 & (c ) & & & & \\
\hline $\operatorname{mov}(\Delta p(-1), 8)$ & & & & & 0.78 & 21.17 \\
\hline $\operatorname{mov}(\Delta p(-1), 3)$ & & & 0.61 & 6.18 & & \\
\hline mov (gap,4) & 0.03 & 2.26 & & & & \\
\hline mov (gap,2) & & & & & 0.04 & 2.42 \\
\hline $\operatorname{gap}(-1)$ & & & 0.03 & 1.55 & & \\
\hline Estimation period & \multicolumn{2}{|c|}{ 1981Q1 2007Q2 } & & \multicolumn{2}{|c|}{ 1982Q2 2007Q2 } \\
\hline SE & \multicolumn{2}{|c|}{0.22} & \multicolumn{2}{|c|}{$\begin{array}{l}\text { 1992Q1 2007Q2 } \\
0.17\end{array}$} & \multicolumn{2}{|c|}{0.23} \\
\hline $\mathrm{R}^{2}$ & \multicolumn{2}{|l|}{0.66} & \multicolumn{2}{|l|}{0.42} & \multicolumn{2}{|l|}{0.83} \\
\hline DW & \multicolumn{2}{|l|}{2.18} & \multicolumn{2}{|l|}{2.35} & \multicolumn{2}{|l|}{1.58} \\
\hline RESET & & & \multicolumn{2}{|l|}{0.13} & \multicolumn{2}{|l|}{0.13} \\
\hline WHITE & \multicolumn{2}{|l|}{0.00} & \multicolumn{2}{|l|}{0.61} & \multicolumn{2}{|l|}{0.00} \\
\hline $\operatorname{LM}(2)$ & \multicolumn{2}{|l|}{0.00} & \multicolumn{2}{|l|}{0.23} & \multicolumn{2}{|l|}{0.15} \\
\hline CHOW STABILITY & \multicolumn{2}{|l|}{0.84} & \multicolumn{2}{|l|}{0.42} & \multicolumn{2}{|l|}{0.02} \\
\hline CHOW PREDICTIVE & \multicolumn{2}{|l|}{0.25} & \multicolumn{2}{|l|}{0.82} & \multicolumn{2}{|l|}{0.64} \\
\hline NORMALITY & \multicolumn{2}{|l|}{0.75} & \multicolumn{2}{|l|}{0.63} & \multicolumn{2}{|l|}{0.30} \\
\hline
\end{tabular}




\section{ANNEX 3: THE MICRO-FOUNDED DYNAMIC GENERAL EQUILIBRIUM MODEL}

This annex details the features of the DGE model used in the paper and provides the micro-foundations of the different equations. It subsequently describes the calibration of the model for the euro area.

\section{Main equations of the DGE model}

\section{Keys to variables:}

\begin{tabular}{|c|c|c|c|}
\hline$C$ & Consumption & $\tau^{w}$ & Tax on labour income \\
\hline$c^{\circ}$ & Consumption by intertemporal optimisers & $\tau^{*}$ & Employer social security contribution \\
\hline$\lambda^{\circ}$ & $\begin{array}{l}\text { Marginal utility of consumption of } \\
\text { intertemporal optimisers }\end{array}$ & $R$ & Gross benefit replacement rate \\
\hline$c^{k}$ & Consumption under liquidity constraints & $T$ & Lump-sum taxes \\
\hline$\lambda^{k}$ & $\begin{array}{l}\text { Marginal utility of consumption of liquidity- } \\
\text { constraint households }\end{array}$ & $Y$ & Output \\
\hline$N$ & Employment & $B$ & $\begin{array}{l}\text { Government bonds bought at the start of } \\
\text { period } t\end{array}$ \\
\hline$W$ & Nominal wage & $i$ & Nominal interest rate \\
\hline$P$ & Price & $\pi$ & Inflation \\
\hline$\tau^{e}$ & Tax on consumption & & \\
\hline
\end{tabular}

\section{Consumption:}

$$
\begin{gathered}
C_{t}=(1-\omega) C_{t}^{o}+\omega C_{t}^{k} \\
1=\beta\left(1+i_{t}\right) E_{t}\left[\lambda_{t+1}^{o} / \lambda_{t}^{o}\right] \\
\lambda_{t}^{o}=\frac{1}{\left(1+\tau_{t}^{\sigma}\right) P_{t}}\left(\frac{1}{C_{t}^{\theta}-h C_{t-1}^{o}}-\frac{\beta h}{C_{t+1}^{o}-h C_{t}^{\theta}}\right) \\
C_{t}^{k}=\frac{1-\tau_{t}^{w}}{1+\tau_{t}^{o}} \frac{W_{t}}{P_{t}} N_{t}+\frac{1-\tau_{t}^{w}}{1+\tau_{t}^{\sigma}}\left(1-N_{t}\right) \frac{W_{t}}{P_{t}} R_{t}-\frac{w}{1+\tau_{t}^{o}} \frac{T_{t}}{P_{t}}
\end{gathered}
$$

Wages:

$$
\frac{W_{t}}{P_{t}}\left[(1-\omega)\left(\frac{1}{C_{t}^{\theta}-h C_{t-1}^{\theta}}-\frac{\beta h}{C_{t+1}^{\theta}-h C_{t}^{\theta}}\right)+\omega \frac{1}{C_{t}^{k}}\right]=\frac{1+\tau_{t}^{e}}{1-\tau_{t}^{W}} \frac{\kappa \eta N_{t}^{\varphi}}{\left(1-R_{t}\right) \eta-1}
$$


ECO/WKP(2008)55

Production:

$$
Y_{t}=N_{t}
$$

Demand:

$$
Y_{t}=C_{t}+\frac{\phi}{2}\left(\frac{N_{t}}{N_{t-1}}-1\right)^{2} N_{t-1}+\frac{\theta}{2}\left(\frac{P_{t}}{P_{t-1}}-1\right)^{2} Y_{t}
$$

Prices:

$$
\begin{aligned}
\theta\left(\frac{P_{t}}{P_{t-1}}-1\right) \frac{P_{t}}{P_{t-1}} & \\
& =1+\theta \beta E_{t}\left[\frac{\lambda_{t+1}^{o}}{\lambda_{t}^{o}}\left(\frac{P_{t+1}}{P_{t}}-1\right) \frac{P_{t+1}}{P_{t}} \frac{Y_{t+1}}{Y_{t}}\right] \\
& +\varepsilon\left[\frac{\left(1+\tau_{t}^{*}\right) W_{t}}{P_{t}}+\phi\left(\left[\frac{Y_{t}}{Y_{t-1}}-1\right]-\beta E_{t}\left[\left(\frac{Y_{t+1}}{Y_{t}}-1\right) \frac{Y_{t+1}}{Y_{t}}\right]+\frac{1}{2}\left(\frac{Y_{t}}{Y_{t-1}}-1\right)^{2} \frac{P_{t} Y_{t-1}}{P_{t-1} Y_{t}}\right)-1\right]
\end{aligned}
$$

\section{Government budget:}

$$
\left(1-\tau_{t}^{W}\right)\left(1-N_{t}\right) W_{t} R_{t}+\left(1+i_{t}\right) B_{t}=\left(\tau_{t}^{w}+\tau_{t}^{2}\right) W_{t} N_{t}+\tau_{t}^{e} P_{t} C_{t}+T_{t}+B_{t+1}
$$

Monetary policy rule:

$$
i_{t}=-\ln \beta+\phi_{\pi} \pi_{t}
$$

\section{Micro-foundations of the equations}

The model equations can be derived from assumptions on the behaviour of households, firms and policy makers.

\section{Households}

The household sector consists of a continuum of households $i \in[0,1]$. A share $\omega$ of these households faces liquidity constraints. Liquidity-constrained households, labelled $k \in[0, \omega]$, have no access to financial markets and consume their current disposable income at each period. By contrast, unconstraint households, labelled $o \in[\omega, 1]$, have full access to financial markets. They can buy and sell assets and transfer income over time.

Lifetime utility is the expected discounted value of utility at each period over an infinite horizon. Utility is additive in the utility from consumption $C_{t}$ and the disutility from work $N_{t}$ :

$$
E_{0} \sum_{t=0}^{\infty} \beta^{t}\left[\ln \left(C_{t}^{i}-h C_{t-1}^{i}\right)-\frac{\kappa}{1+\varphi}\left(N_{t}^{i}\right)^{1+\varphi}\right]
$$


where $0 \leq h \leq 1$ indicates the degree of habit persistence, and $\kappa$ the weight of leisure. The parameters $\beta$ and $\varphi^{\mathbf{- 1}}$ respectively denote the discount factor and the labour supply elasticity. $\mathrm{h}$ is assumed to be zero for the liquidity-constrained households.

Each household $i$ supplies differentiated labour services in a monopolistically competitive labour market. For simplicity the labour services of liquidity-constrained and intertemporally optimising households are assumed to be of comparable quality. Labour inputs are then combined in a CES bundle of the differentiated labour services:

$$
N_{t}=\left[\int_{0}^{1}\left(N_{t}^{i}\right)^{\frac{\eta-1}{\eta}} d i\right]^{\frac{\eta}{\eta-1}}
$$

$\eta$ is the elasticity of substitution between services. Demand for variety $i$ is a function of relative wage and of total labour demand:

$$
N_{t}^{i}=\left(\frac{W_{t}^{i}}{W_{t}}\right)^{-\eta} N_{t}
$$

The budget constraint of unrestricted households is:

$$
\left(1-\tau_{t}^{w}\right) W_{t}^{i} N_{t}^{O}+\left(1-\tau_{t}^{W}\right)\left(1-N_{t}^{O}\right) W_{t} R_{t}+P_{t} D_{t}=\left(1+\tau_{t}^{o}\right) P_{t} C_{t}^{o}+B_{t+1}-\left(1+i_{t}\right) B_{t}+(1-\varpi) T_{t}
$$

with $W_{t}^{i}$ the nominal wage of household $i, W_{t}$ the average nominal wage, $\tau_{t}^{W}$ is the labour income tax, $R_{t}$ the replacement ratio for the non-employed part of the household, $\boldsymbol{P}_{t} D_{t}$ profits, $\boldsymbol{P}_{t} C_{t}^{a}$ nominal consumption, $\tau_{t}^{e}$ the consumption tax rate $B_{t}$ are one-period government bonds bought at the start of period $t, i_{t}$ the nominal interest rate, and $T_{t}$ lump-sum taxes. The parameter $1-\varpi$ is the share of lump-sum taxes levied from the non liquidity-constrained households.

Liquidity-constrained households can neither save income nor borrow against future income. They do not receive any profit. As a result, net household expenditure equals net spending at each period:

$$
\left(1-\tau_{t}^{W}\right) W_{t}^{i} N_{t}^{k}+\left(1-\tau_{t}^{W}\right)\left(1-N_{t}^{k}\right) W_{t} R_{t}=\left(1+\tau_{t}^{\sigma}\right) P_{t} C_{t}^{k}+\varpi T_{t}
$$

\section{Consumption}

Households consume a bundle of differentiated goods, each one being provided by a firm $j \in[0,1]$. Aggregate consumption thus equals:

$$
C_{t}=\left[\int_{0}^{1}\left(C_{t}^{j}\right)^{\frac{z-1}{z}} d j\right]^{\frac{z}{s-1}}
$$

with $\varepsilon$ as the elasticity of substitution between $C_{t}^{j}$. Demand for $C_{t}^{j}$ depends on the relative price of the variety and on the aggregate demand for consumption goods: 


$$
c_{t}^{l}=\left(\frac{P_{t}^{\prime}}{P_{t}}\right)^{-\varepsilon} C_{t}
$$

Intertemporally optimising households choose the consumption path that ensures equality of the discounted marginal utility of consumption expenditure at each point of time. Differentiating utility (2) under the budget restriction (3) gives the marginal utility of consumption:

$$
\lambda_{t}^{o}=\frac{1}{\left(1+\tau_{t}^{\sigma}\right) P_{t}}\left(\frac{1}{C_{t}^{o}-h C_{t-1}^{o}}-\frac{\beta h}{C_{t+1}^{o}-h C_{t}^{o}}\right)
$$

Moreover, the intertemporal optimality condition that determines income transfers, i.e. the optimal amount of saving, reads:

$$
\lambda_{t}^{0}=\beta\left(1+i_{t}\right) E_{t} \lambda_{t+1}^{0}
$$

Combining the first-order conditions (6) and (7) yields the optimal consumption path:

$$
1=\beta\left(1+i_{t}\right) E_{t}\left[\frac{1+\tau_{t}^{e}}{1+\tau_{t+1}^{e}} \frac{P_{t}}{P_{t+1}} \frac{\left(C_{t+1}^{o}-h C_{t}^{o}\right)^{-1}-\beta h\left(C_{t+2}^{o}-h C_{t+1}^{o}\right)^{-1}}{\left(C_{t}^{o}-h C_{t-1}^{o}\right)^{-1}-\beta h\left(C_{t+1}^{o}-h C_{t}^{o}\right)^{-1}}\right]
$$

The liquidity-constrained households spend all their currently disposable income on current consumption. The marginal utility of income, derived from maximising (2) with $h=0$ under restriction (4) is:

$$
\lambda_{t}^{k}=\frac{1}{\left(1+\tau_{t}^{v}\right) P_{t} C_{t}^{k}}
$$

Consumption under the budget constraint (4) equals:

$$
C_{t}^{k}=\frac{1-\tau_{t}^{w}}{1+\tau_{t}^{e}} \frac{W_{t}^{i}}{P_{t}} N_{t}^{k}+\frac{1-\tau_{t}^{w}}{1+\tau_{t}^{e}}\left(1-N_{t}^{k}\right) \frac{W_{t}}{P_{t}} R_{t}-\frac{\varpi}{1+\tau_{t}^{e}} \frac{T_{t}}{P_{t}}
$$

Finally, aggregate consumption equals the weighted average of the consumption levels of both types of households:

$$
C_{t}=(1-\omega) C_{t}^{\circ}+\omega C_{t}^{k}
$$

\section{Labour market}

Labour unions set wage for the differentiated services in a monopolistically competitive labour market. It is assumed that optimising and liquidity-constrained consumers are uniformly distributed across types of labour and hence across unions (see e.g. Galí et al., 2007). At each period, a typical union, representing workers of type $i$, sets the wage to maximise the marginal value of income subject to the labour demand function (2). The optimum wage obtained from differentiating (1) under the constraints (2) and (3) or 
(4) with respect to $W_{t}^{i}$ is: ${ }^{15}$

$$
\kappa \eta\left(\frac{W_{t}^{i}}{W_{t}}\right)^{-\eta(1+\varphi)} \frac{N_{t}^{1+\varphi}}{W_{t}^{i}}+\lambda_{t}\left(1-\tau_{t}^{w}\right)(1-\eta)\left(\frac{W_{t}^{i}}{W_{t}}\right)^{-\eta} N_{t}+\lambda_{t} \eta\left(1-\tau_{t}^{w}\right)\left(\frac{W_{t}^{i}}{W_{t}}\right)^{-(1+\eta)} N_{t} R_{t}=0
$$

All unions target the same wage and wages are fully flexible, so that $W_{t}^{i}=W_{t}$, the previous expression simplifies to:

$$
W_{t}=\frac{\kappa}{1-\tau_{t}^{w}} \frac{N_{t}^{q}}{\lambda_{t}} \frac{\eta}{\left(1-R_{t}\right) \eta-1}
$$

The replacement rate, a proxy of the reservation wage, exerts upward pressures on wages. Because consumption generally differs across both types of households, the union weights labour income using a weighted average of constrained and unconstrained households' marginal utility of consumption, i.e. $\lambda_{t}=(1-\omega) \lambda_{t}^{\circ}+\omega \lambda_{t}^{k}$. Inserting (6) along this weighting scheme yields:

$$
\frac{W_{t}}{P_{t}}\left[(1-\omega)\left(\frac{1}{C_{t}^{O}-h C_{t-1}^{o}}-\frac{\beta h}{C_{t+1}^{o}-h C_{t}^{o}}\right)+\omega \frac{1}{C_{t}^{k}}\right]=\frac{1+\tau_{t}^{o}}{1-\tau_{t}^{W}} \frac{\kappa \eta N_{t}^{\varphi}}{\left(1-R_{t}\right) \eta-1}
$$

Because firms allocate labour demand uniformly across different workers employment is equal across households, i.e. $N_{t}=N_{t}^{o}=N_{t}^{k}$.

\section{Production and prices}

The production sector consists of a continuum of firms $j \in[0,1]$ producing a differentiated product and setting price in a monopolistically competitive product market. Labour is the only input, which yields constant returns to scale. Without loss of generality, the technology parameter can be normalised to one. Consequently, gross output of firm $j$ under this simple production function is:

$$
Y_{t}^{j}=N_{z}^{j}
$$

Each firm faces quadratic employment and price adjustment costs $\Phi_{\mathrm{t}}$ and $\theta_{\mathrm{t}}$ respectively. Adjustment costs are sunk costs that use part of output and drive a wedge between production and consumption. Labour adjustment costs can be interpreted as hiring and firing costs. A common specification of quadratic per-unit adjustment costs of firm $i$ (e.g. Cahuc and Zylberberg, 2004; Hamermesh, 1995; Rotemberg, 1982) is:

15. This first-order condition assumes that unions neglect the effect of wage levels on unemployment transfer levels, e.g. that unions care only about the working insiders. If unions took into account that, given the replacement rate, higher wages imply higher transfers to the unemployed and higher household income, the first-order condition would become

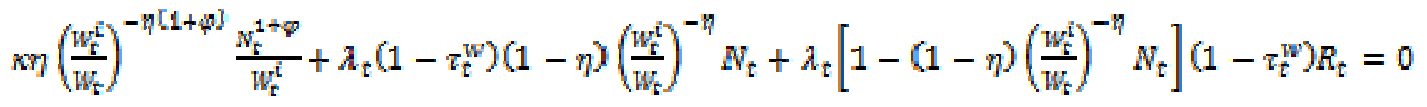

and the subsequent wage setting equation would change accordingly. 


$$
\begin{gathered}
\Phi_{t}^{j}=\frac{\phi}{2}\left(\frac{N_{t}^{j}}{N_{t-1}^{j}}-1\right)^{2} \\
\theta_{t}^{j}=\frac{\theta}{2}\left(\frac{P_{t}^{j}}{P_{t-1}^{j}}-1\right)^{2}
\end{gathered}
$$

The aggregate level of output is:

$$
Y_{t}=\int_{0}^{1} Y_{t}^{j} d j=\int_{0}^{1} C_{t}^{j} d j+\int_{0}^{1} \Phi_{t}^{j} N_{t-1}^{j} d j+\int_{0}^{1} \theta_{t}^{j} Y_{t}^{j} d j
$$

Assuming firms adjust price at the same time as in Rotemberg (1982), there is no relative price dispersion and $P_{t}^{j}=P_{t}$. Following equation (5), consumption demand equally spreads across the product varieties $j$. Symmetry also implies adjustment costs are identical across firms, so that $\int_{0}^{1} \Phi_{t}^{j} N_{t-1}^{j} d j=\Phi_{t} N_{t-1}$ and $\int_{0}^{1} \theta_{t}^{j} Y_{t}^{j} d j=\theta_{t} Y_{t}$. Consequently, aggregate output equals:

$$
Y_{t}=C_{t}+\Phi_{t} N_{t-1}+\theta_{t} Y_{t}
$$

Firms set sales price $P_{t}^{j}$ so as to maximise their discounted stream of profits:

$$
\max _{p_{t}^{j}} D_{0}^{j}=\sum_{t=0}^{\infty} \beta^{t} \frac{\lambda_{t}^{p}}{\lambda_{0}^{g}}\left[\frac{p_{t}^{l}}{P_{t}} Y_{t}^{j}-\left(1+\tau_{t}^{\theta}\right) \frac{W_{t}}{p_{t}} N_{t}^{j}-\Phi_{t}^{j} N_{t-1}^{j}-\theta_{t}^{j} Y_{t}^{j}\right]
$$

where $\beta^{t} \lambda_{t}^{o} / \lambda_{0}^{0}$ is the marginal utility value for the optimising household of an additional unit of real profits generated during period $t$. Differentiating this equation with respect to $P_{t}^{j}$ given the production function (13) together with the definition of employment and price adjustment costs, the demand function $Y_{t}^{j}=\left(P_{t}^{j} / P_{t}\right)^{-E_{z}} Y_{t}$ and the assumption of symmetric behaviour of firms, $P_{t}^{j}=P_{t}$ and $Y_{t}^{j}=Y_{t}$, yields the dynamic price setting equation:

$$
\begin{aligned}
\theta\left(\frac{P_{t}}{P_{t-1}}-1\right) \frac{P_{t}}{P_{t-1}} & \\
& =1+\theta \beta E_{t}\left[\frac{\lambda_{t+1}^{o}}{\lambda_{t}^{\theta}}\left(\frac{P_{t+1}}{P_{t}}-1\right) \frac{P_{t+1}}{P_{t}} \frac{Y_{t+1}}{Y_{t}}\right] \\
& +\varepsilon\left[\frac{\left(1+\tau_{t}^{\theta}\right) W_{t}}{P_{t}}+\phi\left(\left[\frac{Y_{t}}{Y_{t-1}}-1\right]-\beta E_{t}\left[\left(\frac{Y_{t+1}}{Y_{t}}-1\right) \frac{Y_{t+1}}{Y_{t}}\right]+\frac{1}{2}\left(\frac{Y_{t}}{Y_{t-1}}-1\right)^{2} \frac{P_{t} Y_{t-1}}{P_{t-1} Y_{t}}\right)-1\right]
\end{aligned}
$$

Quadratic price adjustment costs reduce the elasticity of goods prices to current production costs and introduce a forward-looking component into pricing decisions. Aggregate demand influences the current level of output and employment because of the sluggish price adjustment. Both employment and price adjustment costs generate gaps between actual output and the production level that would prevail under perfectly flexible markets. ${ }^{16}$ The marginal value of income in equation (15) refers to intertemporal

16. Note that although price adjustment costs introduce persistence in goods prices, they do not generate inflation persistence. In order to generate inflation persistence one would have to include some form of price indexation (e.g. Smets and Wouters, 2003) or backward-looking behaviour in the formation of expectations. 
optimisers only, because liquidity-constrained consumers do not own firms. Without adjustment costs, $\theta=\phi=0$, equation (15) reduces to $P_{t}=\varepsilon(\varepsilon-1)^{-1}\left(1+\tau_{t}^{\theta}\right) W_{t}$. The latter is the standard pricing rule under monopolistic competition and flexible prices, when $\left(1+\tau_{z}^{*}\right) W_{t}$ are the marginal costs of production.

\section{Government}

The government collects wage income tax $\tau_{t}^{w}$, consumption tax $\tau_{t}^{e}$, and employer social security contributions $\tau_{t}^{e}$. It pays transfers at the replacement rate $R_{t}$ to unemployed household members and issues bonds $B_{t+1}$ to balance the budget. It can also levy lump-sum taxes $T_{t}$ to this aim. Public final demand is omitted for simplicity, but this would not substantially modify the results. The government budget constraint is:

$$
\left(1-\tau_{t}^{w}\right)\left(1-N_{t}\right) W_{t} R_{t}+\left(1+i_{t}\right) B_{t}=\left(\tau_{t}^{w}+\tau_{t}^{q}\right) W_{t} N_{t}+\tau_{t}^{\theta} P_{t} C_{t}+T_{t}+B_{t+1}
$$

Forward-looking consumption and price setting behaviour requires a policy rule to ensure the uniqueness and stability of the equilibrium. To keep the analysis simple, policy rates are assumed to react to current inflation:

$$
i_{t}=-\ln \beta+\phi_{\pi} \pi_{t}
$$

\section{Extension 1: Nominal wage stickiness}

A first possible extension of the framework adds nominal wage rigidity as an additional friction to the employment and price adjustment costs of the baseline model. Sluggish nominal wage adjustment is introduced in the form of staggered wage setting and in analogy to the Calvo staggered pricing model (e.g. Canzoneri et al., 2007; Erceg et al., 2000). The model assumes a labour market with differentiated labour inputs and monopolistic competition among suppliers of labour. ${ }^{17}$ Maximising utility (1) under the labour demand function (2) and the budget constraint (3) yields the first-order condition:

$$
\left(W_{t}^{*}\right)^{1+\eta \varphi}=\kappa \frac{\eta}{\eta-1} \frac{E_{0} \sum_{t=0}^{\infty}\left[(\xi \beta)^{t} W_{t}^{(1+\varphi)} N_{t}^{1+\varphi}\right]}{E_{0} \sum_{t=0}^{\infty}\left[(\xi \beta)^{t} \lambda_{t}\left(1-\tau_{t}^{W}\right) W_{t}^{\eta} N_{t}\right]}
$$

with $W_{z}^{*}$ as the optimal wage chosen by households that reset wages and $1-\xi$ as the probability of resetting wages in a given period. The aggregate nominal wage level is then:

$$
W_{t}^{1-\eta}=(1-\xi)\left(W_{t}^{*}\right)^{1-\eta}+\xi W_{t-1}^{1-\eta}
$$

\section{Extension 2: A search-and-matching model of the labour market}

A number of recent contributions have adopted the search-and-matching approach in DGE models to incorporate the effect of frictional unemployment in the analysis (e.g. Blanchard and Galí, 2008; Campolmi and Faia, 2006; Christoffel and Linzert, 2005; Faia, 2006).

17. To limit the complexity of the model the extension restricts itself to the model with intertemporally optimising households only, i.e. the model without liquidity constraints. 
Frictional unemployment allows gross to differ from net flows into and out of unemployment. The framework in the present paper uses the wage setting relationship (12). The derivation explicitly accounts for the impact of structural policies on steady-state labour supply instead of adopting the common assumption of exogenous and constant labour supply. For simplicity we restrict this model extension to an economy without liquidity-constrained consumers, i.e. to $\omega=0$.

Employment $N_{t}$ is modelled as the level of previous employment net of job separations plus current job matches:

$$
N_{t}=(1-\rho) N_{t-1}+m\left(U_{t}, V_{t}\right)
$$

where $\rho$ is an exogenous separation rate, and $m\left(U_{t}, V_{t}\right)$ are current job matches given initial unemployment $U_{t}$ and vacancies $V_{t}$. The matching function has a Cobb-Douglass form (e.g. Campolmi and Faia, 2006; Faia, 2006):

$$
m\left(U_{t}, V_{t}\right)=\mu U_{t}^{\xi} V_{t}^{1-\xi}
$$

with $\mu \in(0,1)$ as the matching technology and $\xi \in(0,1)$ specifying the elasticity of matches with respect to unemployment. Unemployment at the start of the period $U_{t}$, is the gap between labour supply, i.e. optimal employment, in the absence of employment and price adjustment costs $L_{t}^{z}$, and actual beginningof-period employment: $U_{t}=L_{t}^{s}-(1-\rho) N_{t-1}{ }^{18}$ The ratio of vacancies over unemployment, $\vartheta_{t}=V_{t} / U_{t}$, is a measure of labour market tightness that allows rewriting the matching function:

$$
m\left(\vartheta_{t}, U_{t}\right)=\mu \vartheta_{t}^{1-\xi} U_{t}
$$

The probability for an unemployed to find a job is $q_{t}=m_{t} / U_{t}=\mu v_{t}^{1-\xi}$, which yields:

$$
m\left(\vartheta_{t}, U_{t}\right)=q_{t} U_{t}
$$

The level of employment in the absence of employment or price adjustment costs can be derived from combining equations (12) and (15) under $\theta=\phi=0$. Further using $C_{t}=L_{t}^{s}$ in this case from equation (14) yields:

$$
\frac{1}{L_{t}^{z}-h L_{t-1}^{s}}-\frac{\beta h}{E_{t} L_{t+1}^{s}-h L_{t}^{z}}=\frac{\varepsilon}{\varepsilon-1} \frac{\left(1+\tau_{t}^{c}\right)\left(1+\tau_{t}^{z}\right)}{1-\tau_{t}^{w}} \frac{\kappa \eta\left(L_{t}^{s}\right)^{\varphi}}{\left(1-R_{t}\right) \eta-1}
$$

Thus, $L_{t}^{g}$ is full employment consistent with a level of production distorted labour and price costs. The rate of unemployment is $U_{t} / L_{t}^{s}$.

Adjustment costs are assumed to apply to gross flows, $N_{t}-(1-\rho) N_{t-1}$, consistent with Hamermesh (1995) The adjustment cost term then reads:

18. This contrasts with the previously cited research. The latter generally defines unemployment as the gap between a constant work force, often normalised to unity, and actual employment. The definition adopted here accounts for the fact that distortions from fiscal policy and monopolistic competition affect optimal labour supply and consequently also the labour market tightness. 


$$
\Phi_{t}^{g, j}=\frac{\phi}{2}\left(\frac{N_{t}^{j}}{N_{t-1}^{j}}+\rho-1\right)^{2}
$$

The dynamic price setting equation becomes:

$$
\begin{aligned}
& \theta\left(\frac{P_{t}}{P_{t-1}^{\prime}}-1\right) \frac{P_{t}}{P_{t-1}} \\
& =1+\theta E_{t}\left[\beta \frac{\lambda_{t+1}^{o}}{\lambda_{t}^{o}}\left(\frac{P_{t+1}}{P_{t}}-1\right) \frac{P_{t+1}}{P_{t}} \frac{Y_{t+1}}{Y_{t}}\right]+\varepsilon\left[\frac{\left(1+\tau_{t}^{*}\right) W_{t}}{P_{t}}-1\right] \\
& +\phi \varepsilon\left(\left[\frac{Y_{t}}{Y_{t-1}}+\rho-1\right]-\beta E_{t}\left[\left(\frac{Y_{t+1}}{Y_{t}}+\rho-1\right) \frac{Y_{t+1}}{Y_{t}}\right]+\frac{1}{2}\left(\frac{Y_{t}}{Y_{t-1}}+\rho-1\right)^{2} \frac{P_{t} Y_{t-1}}{P_{t-1} Y_{t}}\right)
\end{aligned}
$$

The overall resource constraint of the economy with adjustment costs on gross labour flows is

$$
Y_{t}=C_{t}+\Phi_{t}^{g} N_{t-1}+\theta_{t} Y_{t}
$$

\section{Calibration}

The calibration of the model parameters builds on the estimated euro area DGE models of Coenen et al. (2007), Grenouilleau et al. (2007) and Sahuc and Smets (2008) as well as mark-up estimates of Christopoulou and Vermeulen (2008) and tax and benefit data from OECD (2007b) (see Table A.3.1).

The parameter of price adjustment costs matches the empirical evidence on average price duration in the euro area and the United States (Bils and Klenow, 2004; Altissimo et al., 2006). The value of $25 \%$ for the share of liquidity-constrained households in Figures 7-8 is taken from Coenen et al. (2007), while the probability of 0.25 is close to the Sahuc and Smets (2008) estimates for both the euro area and the United States. The fiscal parameters follow the OECD (2007b) tax and benefits data for euro area countries and coincide with those in Coenen et al. (2007). Unemployment in the model being in the model for second earner, the average replacement rate is for a spouse in work,. The estimated average elasticity of substitution in the goods market in Christopoulou and Vermeulen (2008) suggests a 25\% price mark-up. The elasticity of substitution between labour services from Coenen et al. (2007) implies a 20\% steady-state wage mark-up. The remaining parameter values are taken from the euro area models of Coenen et al. (2007) and Smets and Wouters (2003) and are in line with other empirical studies. 
Table A.3.1. Calibration of the parameters

\begin{tabular}{|c|c|c|c|}
\hline Name & Symbol & Value & Source \\
\hline $\begin{array}{l}\text { Employment adjustment costs } \\
\text { Euro area } \\
\text { United States }\end{array}$ & $\theta$ & $\begin{array}{l}63 \\
30\end{array}$ & Grenouilleau et al. (2007) \\
\hline $\begin{array}{l}\text { Price adjustment costs } \\
\text { Euro area } \\
\text { United States }\end{array}$ & $\psi$ & $\begin{array}{l}21 \\
3.40\end{array}$ & Grenouilleau et al. (2007) \\
\hline Consumption tax & $\mathrm{T}^{\mathrm{C}}$ & 0.18 & OECD (2007b) \\
\hline Labour income tax & $T^{\mathrm{w}}$ & 0.24 & OECD (2007b) \\
\hline Employer social security contributions & $T^{e}$ & 0.22 & OECD (2007a) \\
\hline Replacement rate & $\mathrm{R}$ & 0.25 & OECD (2007a) \\
\hline Elasticity of substitution between types of labour & $\eta$ & 6.00 & Coenen et al. (2007) \\
\hline Elasticity of substitution between types of goods & $\varepsilon$ & 5.00 & Christopoulou and Vermeulen (2008) \\
\hline Habit persistence & $\mathrm{h}$ & 0.85 & Grenouilleau et al. (2007) \\
\hline Share of liquidity-constrained households & $\omega$ & 0.25 & Coenen et al. (2007) \\
\hline Disutility weight of labour & $\mathrm{K}$ & 1.00 & Coenen et al. (2007) \\
\hline Discount factor & $\beta$ & 0.99 & Coenen et al. (2007) \\
\hline Inverse of labour supply elasticity & $\varphi$ & 2.20 & Smets and Wouters (2003) \\
\hline Policy response to inflation & $\phi_{\pi}$ & 1.50 & Galí et al. (2007) \\
\hline Probability of wage re-setting & $1-\xi$ & 0.25 & Sahuc and Smets (2008) \\
\hline Job finding probability & $q$ & 0.60 & Campolmi and Faia (2007) \\
\hline Exogenous job separation rate & $\rho$ & 0.08 & Christoffel and Linzert (2005) \\
\hline
\end{tabular}




\section{ANNEX 4: ADDITIONAL IMPULSE RESPONSES FROM THE DGE MODEL}

Figure A.4.1. Impact of a one percentage-point cut in the benefit replacement rate

Percentage change compared to baseline, percentage points for inflation and interest rates
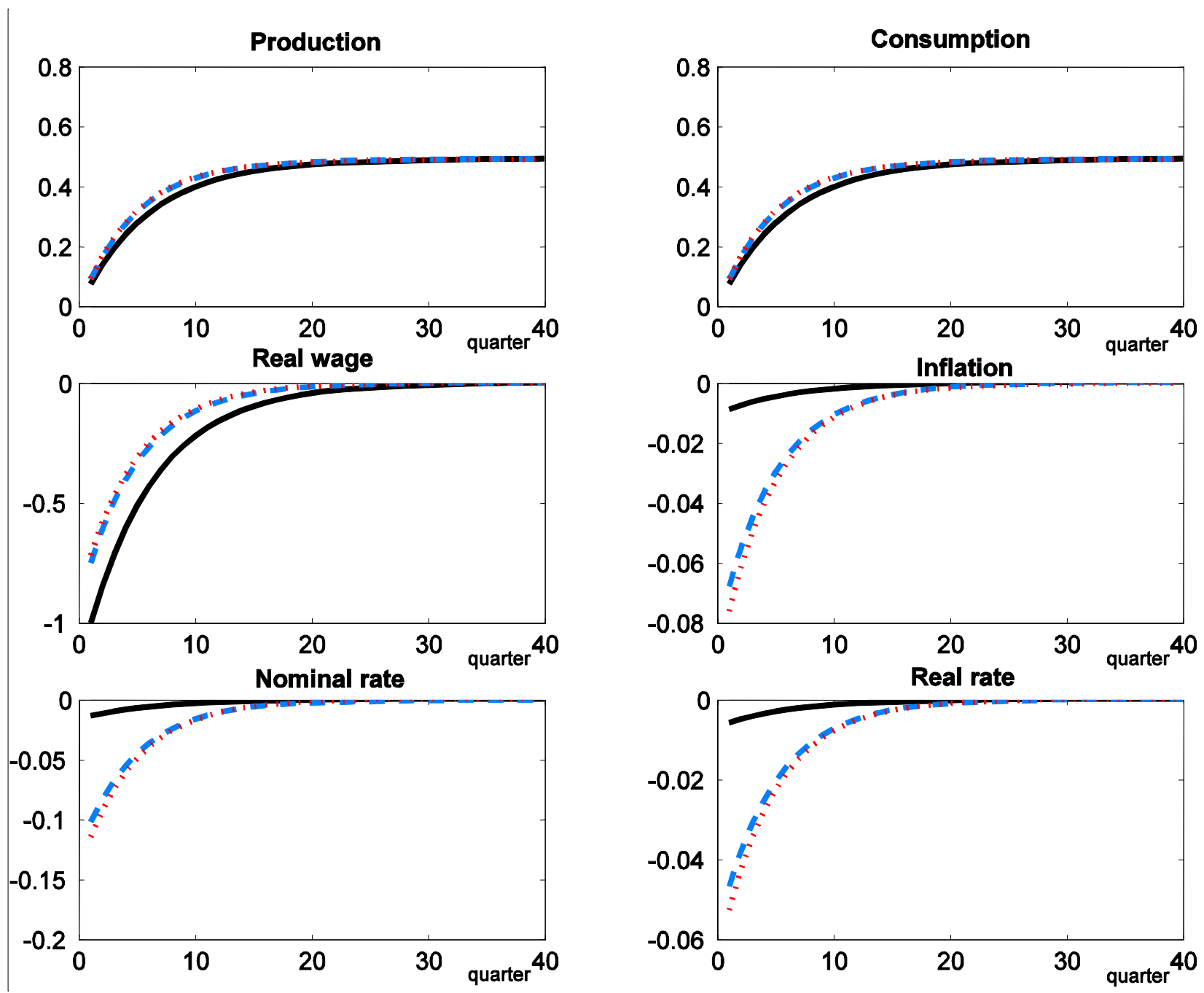

—— Euro area —— Euro area with US labour adjustment costs

---- Euro area with US labour and price adjustment costs 
Figure A.4.2. Impact of a one percentage-point cut in social security contributions

Percentage change compared to baseline, percentage points for inflation and interest rates
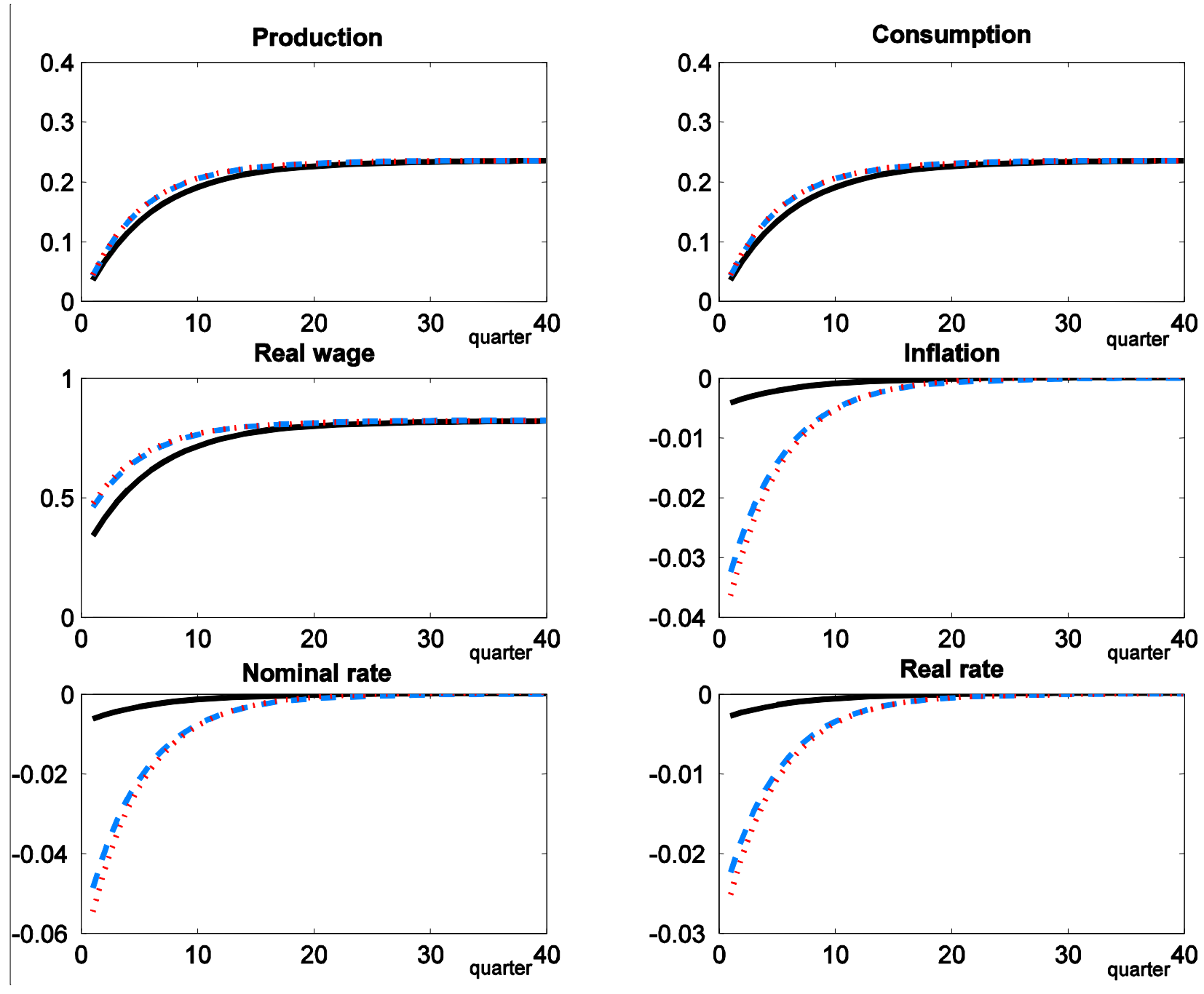

—_ Euro area —_ Euro area with US labour adjustment costs

---- Euro area with US labour and price adjustment costs 
Figure A.4.3. One percentage-point cut in the benefit replacement rate in the search-and-matching model

Percentage change compared to baseline, percentage points for inflation and interest rates
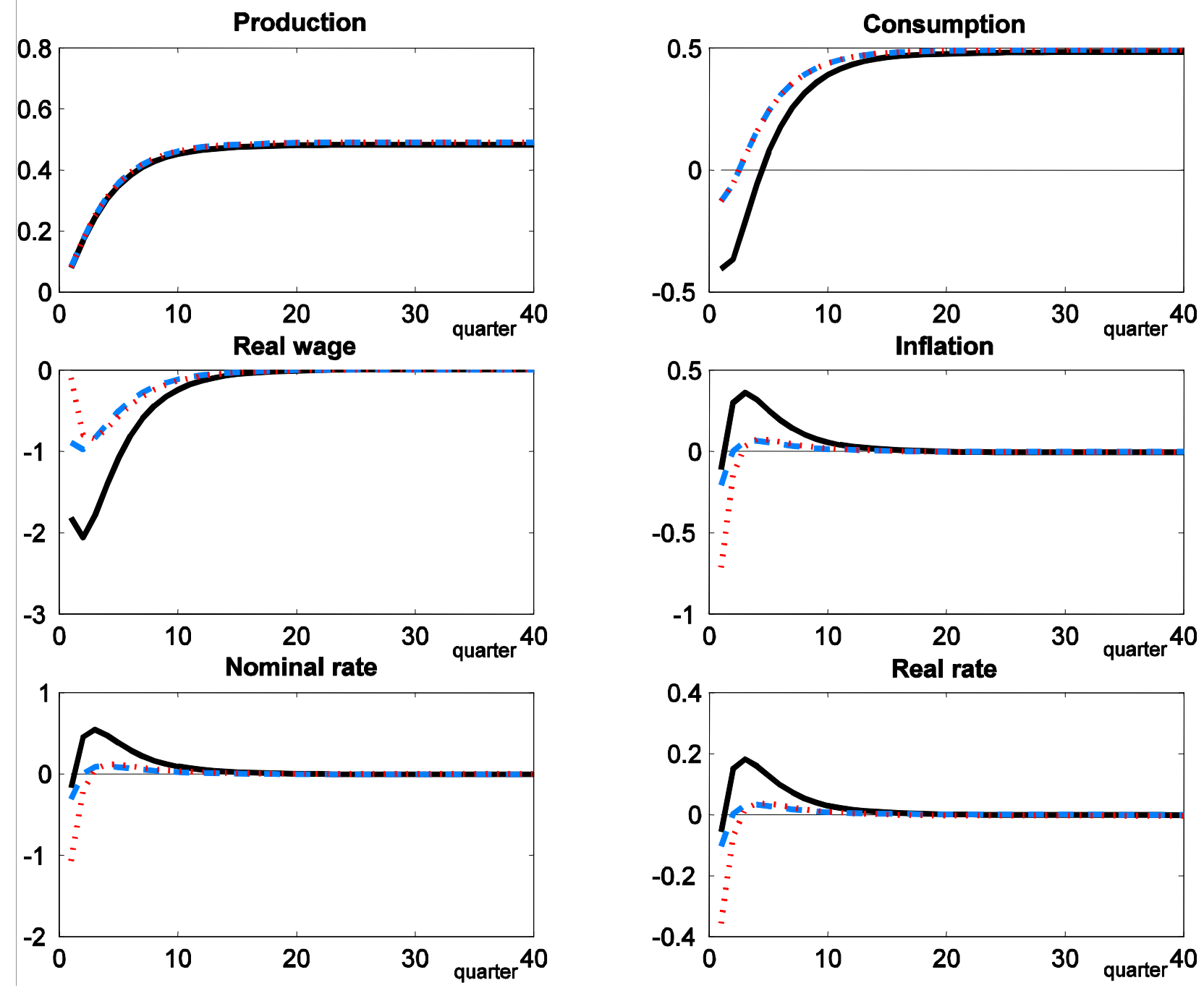

__ Euro area —_ Euro area with US labour adjustment costs

---- Euro area with US labour and price adjustment costs 
Figure A.4.4. One percentage point cut in the social security contributions in the search-and-matching model Percentage change compared to baseline, percentage points for inflation and interest rate
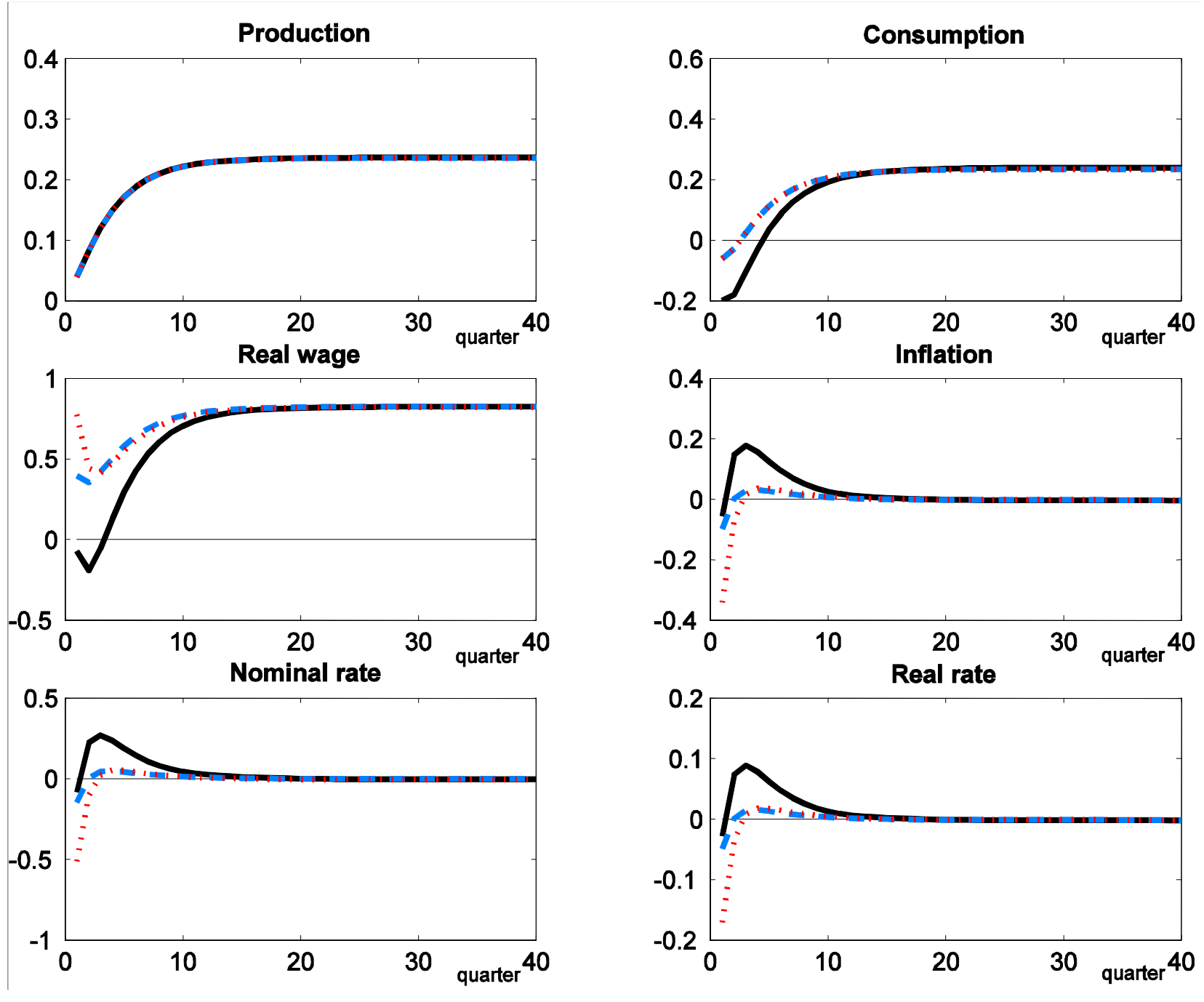

Euro area —— Euro area with US labour adjustment costs

---- Euro area with US labour and price adjustment costs 
ECO/WKP(2008)55

Annex 5: Detailed results of the neo-Keynesian simulations

\section{Effects of a one percentage-point NAIRU reduction}

Change compared to baseline

\begin{tabular}{|c|c|c|c|c|c|c|c|c|}
\hline & Quarters & 1 & 4 & 10 & 20 & 40 & 80 & Long-term \\
\hline \multicolumn{9}{|c|}{ UNITED STATES } \\
\hline \multirow[t]{2}{*}{ Real GDP } & $\begin{array}{l}\text { without monetary } \\
\text { reaction }\end{array}$ & 0.0 & 0.0 & 0.0 & 0.1 & 0.4 & 0.7 & 0.7 \\
\hline & with monetary reaction & 0.0 & 0.1 & 0.4 & 0.7 & 0.7 & 0.7 & 0.7 \\
\hline \multirow[t]{2}{*}{ Core inflation } & $\begin{array}{l}\text { without monetary } \\
\text { reaction }\end{array}$ & 0.0 & -0.1 & -0.1 & -0.2 & -0.2 & -0.1 & 0.0 \\
\hline & with monetary reaction & 0.0 & -0.1 & -0.1 & -0.1 & -0.1 & -0.1 & 0.0 \\
\hline \multirow[t]{2}{*}{ Employment } & $\begin{array}{l}\text { without monetary } \\
\text { reaction }\end{array}$ & 0.0 & 0.0 & 0.0 & 0.1 & 0.4 & 0.8 & 1.0 \\
\hline & with monetary reaction & 0.0 & 0.1 & 0.3 & 0.6 & 0.8 & 0.9 & 1.0 \\
\hline \multirow[t]{2}{*}{ Wage } & $\begin{array}{l}\text { without monetary } \\
\text { reaction }\end{array}$ & 0.0 & 0.0 & 0.0 & -0.1 & 0.0 & 0.0 & 0.0 \\
\hline & with monetary reaction & 0.0 & 0.0 & 0.0 & 0.0 & 0.0 & 0.0 & 0.0 \\
\hline \multirow[t]{2}{*}{ Consumption } & $\begin{array}{l}\text { without monetary } \\
\text { reaction }\end{array}$ & 0.0 & 0.0 & 0.0 & 0.0 & 0.3 & 0.6 & 0.7 \\
\hline & with monetary reaction & 0.0 & 0.0 & 0.2 & 0.5 & 0.7 & 0.7 & 0.7 \\
\hline \multirow[t]{2}{*}{ Investment } & $\begin{array}{l}\text { without monetary } \\
\text { reaction }\end{array}$ & 0.0 & 0.0 & 0.0 & 0.3 & 1.2 & 1.0 & 0.7 \\
\hline & with monetary reaction & 0.0 & 0.6 & 2.8 & 4.1 & 1.8 & 1.5 & 0.7 \\
\hline $\begin{array}{l}\text { Real interest } \\
\text { rate }\end{array}$ & with monetary reaction & -0.4 & -0.3 & -0.2 & -0.1 & -0.1 & 0.0 & 0.0 \\
\hline
\end{tabular}




\begin{tabular}{|c|c|c|c|c|c|c|c|c|}
\hline & Quarters & 1 & 4 & 10 & 20 & 40 & 80 & Long-term \\
\hline \multicolumn{9}{|l|}{ EURO AREA } \\
\hline \multirow[t]{2}{*}{ Real GDP } & $\begin{array}{l}\text { without monetary } \\
\text { reaction }\end{array}$ & 0.0 & 0.0 & 0.0 & 0.1 & 0.3 & 0.6 & 0.7 \\
\hline & with monetary reaction & 0.0 & 0.1 & 0.2 & 0.4 & 0.6 & 0.7 & 0.7 \\
\hline \multirow[t]{2}{*}{ Core inflation } & without monetary & -0.1 & -0.1 & -0.3 & -0.6 & -0.9 & -1.1 & 0.0 \\
\hline & with monetary reaction & -0.1 & -0.1 & -0.3 & -0.5 & -0.8 & -0.8 & 0.0 \\
\hline \multirow[t]{2}{*}{ Employment } & $\begin{array}{l}\text { without monetary } \\
\text { reaction }\end{array}$ & 0.0 & 0.0 & 0.0 & 0.1 & 0.3 & 0.7 & 1.0 \\
\hline & with monetary reaction & 0.0 & 0.0 & 0.1 & 0.3 & 0.5 & 0.8 & 1.0 \\
\hline \multirow[t]{2}{*}{ Wage } & $\begin{array}{l}\text { without monetary } \\
\text { reaction }\end{array}$ & 0.0 & 0.0 & 0.0 & 0.0 & 0.0 & 0.0 & 0.0 \\
\hline & with monetary reaction & 0.0 & 0.0 & 0.0 & 0.0 & 0.0 & 0.0 & 0.0 \\
\hline \multirow[t]{2}{*}{ Consumption } & $\begin{array}{l}\text { without monetary } \\
\text { reaction }\end{array}$ & 0.0 & 0.0 & 0.0 & 0.0 & 0.1 & 0.4 & 0.7 \\
\hline & with monetary reaction & 0.0 & 0.1 & 0.1 & 0.3 & 0.4 & 0.6 & 0.7 \\
\hline \multirow[t]{2}{*}{ Investment } & $\begin{array}{l}\text { without monetary } \\
\text { reaction }\end{array}$ & 0.0 & 0.0 & 0.0 & 0.1 & 0.4 & 0.7 & 0.7 \\
\hline & with monetary reaction & 0.0 & 0.3 & 1.2 & 1.8 & 2.2 & 2.2 & 1.2 \\
\hline \multirow[t]{2}{*}{$\begin{array}{l}\text { Real interest } \\
\text { rate }\end{array}$} & with monetary reaction & -0.4 & -0.4 & -0.4 & -0.4 & -0.4 & -0.4 & -0.1 \\
\hline & Quarters & 1 & 4 & 10 & 20 & 40 & 80 & Long-term \\
\hline \multicolumn{9}{|l|}{ FRANCE } \\
\hline \multirow[t]{2}{*}{ Real GDP } & $\begin{array}{l}\text { without monetary } \\
\text { reaction }\end{array}$ & 0.0 & 0.0 & 0.0 & 0.1 & 0.4 & 0.9 & 0.7 \\
\hline & with monetary reaction & 0.0 & 0.0 & 0.0 & 0.1 & 0.4 & 0.9 & 0.7 \\
\hline \multirow[t]{2}{*}{ Core inflation } & $\begin{array}{l}\text { without monetary } \\
\text { reaction }\end{array}$ & -0.1 & -0.1 & -0.3 & -0.4 & -0.5 & -0.3 & 0.0 \\
\hline & with monetary reaction & -0.1 & -0.1 & -0.3 & -0.4 & -0.5 & -0.3 & 0.0 \\
\hline \multirow[t]{2}{*}{ Employment } & $\begin{array}{l}\text { without monetary } \\
\text { reaction }\end{array}$ & 0.0 & 0.0 & 0.0 & 0.1 & 0.3 & 0.8 & 1.0 \\
\hline & with monetary reaction & 0.0 & 0.0 & 0.0 & 0.1 & 0.3 & 0.8 & 1.0 \\
\hline \multirow[t]{2}{*}{ Wage } & $\begin{array}{l}\text { without monetary } \\
\text { reaction }\end{array}$ & 0.0 & 0.0 & -0.1 & -0.1 & -0.1 & 0.0 & 0.0 \\
\hline & with monetary reaction & 0.0 & 0.0 & -0.1 & -0.1 & -0.1 & 0.0 & 0.0 \\
\hline \multirow[t]{2}{*}{ Consumption } & $\begin{array}{l}\text { without monetary } \\
\text { reaction }\end{array}$ & 0.0 & 0.0 & 0.0 & 0.0 & 0.1 & 0.6 & 0.7 \\
\hline & with monetary reaction & 0.0 & 0.0 & 0.0 & 0.0 & 0.1 & 0.6 & 0.7 \\
\hline \multirow[t]{2}{*}{ Investment } & $\begin{array}{l}\text { without monetary } \\
\text { reaction }\end{array}$ & 0.0 & 0.0 & 0.1 & 0.3 & 0.9 & 1.4 & 0.7 \\
\hline & with monetary reaction & 0.0 & 0.0 & 0.2 & 0.5 & 1.1 & 1.4 & 0.7 \\
\hline $\begin{array}{l}\text { Real interest } \\
\text { rate }\end{array}$ & with monetary reaction & -0.1 & -0.1 & -0.1 & -0.1 & -0.1 & 0.0 & 0.0 \\
\hline
\end{tabular}


ECO/WKP(2008)55

\section{WORKING PAPERS}

The full series of Economics Department Working Papers can be consulted at www.oecd.org/eco/Working_Papers/

646. The challenge of monetary policy in Turkey

(October 2008) Olcay Çulha, Ali Çulha and Rauf Gönenç

645. Improving cost-effectiveness in the health-care sector in Iceland

(October 2008) Hannes Suppanz

644. Understanding Russian regions' economic performance during periods of decline and growth - an Extreme Bound Analysis approach

(October 2008) Rüdiger Ahrend

643. Do tax structures affect aggregate economic growth? Empirical evidence from a panel of OECD countries

(October 2008) Jens Arnold

642. Accounting for one-off operations when assessing underlying fiscal positions

(October 2008) Isabelle Joumard, Makoto Minegishi, Christophe André, Chantal Nicq and Robert Price

641. Do corporate taxes reduce productivity and investment at the firm level? Cross-country evidence from the Amadeus dataset

(October 2008) Cyrille Schwellnus and Jens Arnold

640. The challenge of rapidly improving transport infrastructure in Poland

(September 2008) Rafal Kierzenkowski

639. Bridging the housing gap in Poland

(September 2008), Rafal Kierzenkowski

638. Improving the business and investment climate in Indonesia

(September 2008), Diego Moccero

637. Growth performance and policy challenges

(September 2008), Luiz de Mello

636. A taxonomy of instruments to reduce greenhouse gas emissions and their interactions

(September 2008), Romain Duval

635. Quantifying the effect of financial conditions on US activity

(September 2008) Stéphanie Guichard and David Turner

634. Have long-term financial trends changed the transmission of monetary policy

(September 2008), Stéphanie Guichard and David Turner

633. Raising education achievement and breaking the cycle of inequality in the United Kingdom

(August 2008) Anne-Marie Brook 


\section{$\mathrm{ECO} / \mathrm{WKP}(2008) 55$}

632. The euro changeover in the Slovak Republic: implications for inflation and interest rates (August 2008) Felix Hüfner and Isabell Koske

631. Tax reform for efficiency and fairness in Canada (August 2008) Alexandra Bibbee

630. Reforming the Polish Tax System to Improve its Efficiency (August 2008) Alain de Serres

629. Modernising Canada's Agriculture Policies (August 2008) Peter Jarrett and Shuji Kobayakawa

628. Recent trends and structural breaks in US and EU15 labour productivity growth (August 2008) Laure Turner and Hervé Boulhol

627. Health Status Determinants: Lifestyle, Enviroment, Health Care Resources and Efficiency (August 2008) Isabelle Joumard, Christophe André, Chantal Nicq and Olivier Chatal

626. Market Mechanisms in Public Service Provision (August 2008) Hansjörg Blöchliger

625. Improving human capital formation in India (July 2008) Sean M. Dougherty and Richard Herd

624. Labour regulation and employment dynamics at the state level in India (July 2008) Sean M. Dougherty

623. India's growth pattern and obstacles to higher growth (July 2008) Sean M. Dougherty, Richard. Herd, Thomas. Chalaux and Abdul. Erumban

622. Reaping the benefits of stronger competition in network industries in Germany (July 2008) Nicola Brandt

621. The Usefulness of Output Gaps for Policy Analysis (July 2008) Isabell Koske and Nigel Pain

620. Taxation and Economic Growth (July 2008) Åsa Johansson, Christopher Heady, Jens Arnold, Bert Brys and Laura Vartia

619. Coping with labour shortages: How to bring outsiders back to the labour market (July 2008) Ekkehard Ernst

618. Achieving sustainability of the energy sector in Canada (June 2008) Annabelle Mourougane

617. The Dutch tax-benefit system and life-cycle employment. Outcomes and reform options (June 2008) Ekkehard Ernst and Timo Teuber

616. Regulation, Allocative Efficiency and Productivity in OECD Countries: Industry and Firm-Level Evidence

(May 2008) Jens Arnold, Giuseppe. Nicoletti, and Stefano Scarpetta 